\title{
ILIINOIS
}

atural

Iristory

Survey

BULLETIN

\section{A Comparative Study of Two Components of the Poinsettia Root Rot Complex}

t S. Perry

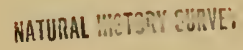

NoV? 1971

LIBRARY

THE LIBRARY OF THE

SEP 1 r $|y /|$

IF ILLINOIS

TMENT OF REGISTRATION AND EDUCATION

UNIVERSITY OF ILLINOIS

AT URBANA-CHAMPAIGN

RAL HISTORY SURVEY DIVISION

NA, ILLINOIS 


\section{ERRATA}

age 437, Figure 3 age 439, Figure 4 age 440, Figure 5 age 441, Figure 7
Should have caption from Fig. 5, page 440

Should have caption from Fig. 3, page 437 Should have caption from Fig. 4, page 439 Caption should read: The colony on the righ was exposed to constant light for 14 days, while the colony on the left was maintaine in the dark for the same period. 


\section{IIIINOIS}

\section{atural Iristory Survey}

\section{BULLETIN}

\section{A Comparative Study of Two Components of the Poinsettia Root Rot Complex}

Pobert S. Perry 
BOARD OF NATURAL RESOURCES AND CONSERVATION

Wulliam H. Robinson, Chairman; TIOMAS PARK, Ph.D., Biology; L. L. Sloss, Ph.D., Geology

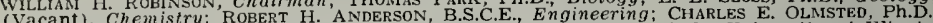
(Vacant), Chem intinois: Forestry; W. L. EvERITT, E.E., Ph.D., Representing the President of Southern Illinois University.

\section{NATURAL HISTORY SURVEY DIVISION, Urbana, Illinois}

SCIENTIFIC AND TECHNICAL STAFF

GEORGE SPRUGRL, JR., Ph.D., Chief

ALICE P. CAMPBELL, B.A., Secretary to the Chief

Section of Economic Entomology

WILLIAN H. LUCKMANN, Ph.D., Entomologist and Head

WILLIS N. BRUCE, Ph.D., Entomologist

WAYNE I HOW', Ph.D., Entomologist

STEVENSON MOORE, III, Ph.D., Entomologist, Extension

HOWARD B. PETTY, Ph.D., Entomologist, Exten-

sion
JAMES E. APPLEBY, Ph.D., Associate Entomologist

EDWARD J. ARMBRUST, Ph.D., Associate Entomologist

MARCOS KOGAN, Ph.D., Associate Entomologist

JOSEPH V. MADDOX, Ph.D., Associate Entomologist

RONALD H. MEYER, Ph.D., Associate Entomologist

ROBERT D. PAUSCII, Ph.D., Associate Entomologist

RalPi E. Sechriest, Ph.D., Associate Entomologist

GEORGE L. GODFREY, Ph.D., Assistant Entomoloyist

Clarence E. White, B.S., Assistant Entomologist

KEUN S. PARK, M.S., Assistant Chemist

SUE E. WATkiNs, Supervisory Assistant

ROSCOE RANDELL, Ph.D., Assistant Professor, Extension

DoNalo E. KUHLiaN, Ph.D., Instructor, Exten$\operatorname{sion}$

TIM COOLEY, M.A., Assistant Specialist, Extension

JEAN G. WILSON, B.A., Supervisory Assistant

MARTHA P. NICHOLS, M.S., Research Assistant

KeTURAIt REINBOLD, M.S., Research Assistant

LOWELL DAVIS Technical A ssistant

NANCY D. DEWITT, B.S., Technical Assistant

MARCIA JaNES, B.S., Technical Assistant

LU-PING KAN, M.S., Technical Assistant

MARIE MONKMIAN, M.S., Technical Assistant

STEPIIEN ROBERTS, B.S., Technical Assistant

Dovglas K. SELL, B.S. Technical Assistant

JoIN T. SHAW, B.S., Technical Assistant

\section{Section of Botony and}

\section{Plont Pathology}

J. Cenric CARTer, Ph.D., Plant Pathologist and Head

RoBert A. Evers, Ph.D., Botan ist

JUNIUS L. FORSBERG, Ph.D., Plant Pathologist

EUGENE B. HIMELICK, Ph.D., Plant Pathologist

R. DAN NEELY, Ph.D., Plant Pathologist

D. F. SCHOENEWEISS, Ph.D. Associate plant Pathologist

J. LELAND CRANE, Ph.D., Assistant Mycologist

WALTER HARTSTIRN, Ph.D., Assistant Plant Pathologist

BETTY S. NELSON, Technical Assistant

GENE E. REID, Technical Assistant

Section of Aquotic Biology

GEORGE W. BENNETT, Ph.D., Aquatic Biologist and Heal

D. HOMER BuCK, Ph.D., Aquatic Biologist

R. Weloon LARIMORE, Ph.D., Aquatic Biologist

WILLIAN C STARRETT, Ph.D." Aquatic Biologist

RoBert C. Hiltibran, Ph.D., Biochemist

WILLIAM F. CHILDERS, Ph.D., Associate Aquatic Biologist

DoNalo F. HANSEN, Ph.D., Associate Aquatic Biologist

RiCliaRD J. BAUR, M.S., Research Assistant

DENNIS L. DOOLEY, Technical Assistant

Mary Frances Martin, Technical Assistant

ROBERT F. RANDALL, Ph.D., Technical Assistant

KENNETH R. WALKER, Technical Assistant

C RUSSELL ROSE, Field Assistant

WARREN U. BRIGHAM, M.S., Junior Technical Assistant

CONSUlTANTS: PARASITOLOGY, NORMAN D. LEVINE, Ph.D. Professor of Veterinary Parasitology and Veterinary Research, University of Illinois; WILDLIFE RESEARCH, WILLARD D. KLIMISTRA, Ph.D., Professor of Zoology and Director of Cooperative Wildlife Research, Southern Illinois University. STATISTICS, HORACE W. NORTON, Ph. Professor of Statistical Design and Analysis, University; STATSTICS, HORACE W. NORTON, Ph.D. Professor of Stalistical Design afessor of Entomology, sity of Illinois; ENTOMOLOGY, GILBERT P. WALdBAuER, Ph.D., Associate Professor of Entomolog University of Illinois.
Section of Founistic Surveys and

Insect Identificotion

PIILIP W. SHITH, Ph. Taxonomist and Heal WALLACE F. LABERGE, Ph.D Taxonomist

MILTON W. SANDERSON, Ph.D., Taxonomist

LEWIS J. STANNARD, JR., Ph.D., Taxonomist

ROBERT W. POOLE, Ph.D., Assistant Taxonomist OHN D.

DONALO W. WEBB, M.S., Assistant Taxonomist

RODERICK $\dot{R}$. InWIN, Research Affiliate

BERNICE P. SWEENEY, Junior Professional Scientist

Section of Wildlife Research

Glen C. SANDERSon, Ph.D., Wildlife Specialist and Head

FRANK C. BELlROSE, B.S., IVildlife Specialist

RABER, Ph.D., Wilalife Specialist Specialist

W. W. Cocinan, JR., B.S., Associate Wildlifc Specialist

ILLIAM R. EDWARDS, M.S., Associate Wildlife Specialist

ACK A. ELLIS, M.S., Associate Wildlife Specialist

Specialist

CHARLES M. NIXON, M.S., Associate Wildlife Specialist cialist

SerT E.

G. BLAIR JOSELYN, M.S., Assistant Wildlife Specialist

GEORGE B. ROSE, Ph.D., Assistant Willlife Specialist

divid R. Vance, M.S., Assistant Wildlife Specialist Specialist

RONALD E. DUZaN, Technical Assistant

NORML J. HUBBARD, Technical Assistant

MARY ANN KJOS, Technical Assistant

HELEN C SCHULTZ, M.A. Technical Assistant

HILDA WIESENMEYER, Technical Assistant

ELEANORE WILSON, Technical Assistant

ROBERT D. CROMPTON, Field Assistant

JAMIES W. SEETS, Laboratory Assistant

Section of Administrotive Services

ROBERT O. WATSON, B.S., Administrator and Heall

Wilma G. Dillaman, Property Control and Trust Accounts

ROBERT O. ELLIS, Assistant for Operations

LLOYD E. HUFF MIAN, Stockroom Manager Services

MELVIN E. ScHWARTZ, Financial Records

JAMIES E. SERGENT, Greenhouse Superintendent

Publicotions ond Public Relotions

OWEN F. GLISSENDORF, M.S., Technical Editor

ROBERT iM. ZEWADSKI, M.S., A ssociate Technical Elitor

SiIRley MCClellaN, Assistant Technical Editor

WILMER D. ZEIIR, Technical Photographer Technical Librory

DoRIS F. DODDS, B.A., M.S.L.S., Technical Librarian

JEN ICKES, B.A., M.S.L.S., Assistant Technical Librarian
WILLIAM L. ANDERSON, M.A., Associate Wilalifo

StANLEY L. ETTER, M.S., Assistant Wildlife Spe- 


\section{CONTENTS}

ACKNOWLEDGMENTS

LITERATURE REVIEW

Fungi

Media

Poinsettias

METHODS

Microscopic Examinations …................................................................. 423

$\mathrm{pH}$ Studies

Temperature Studies

Light Studies

Pathogenicity Tests

Morphology of Thielaviopsis basicola

Colony Characteristics of $T$. basicola

T. basicola on Poinsettias

Morphology of Chalaropsis thiclavioides

Colony Characteristics of $C$. thielavioides

C. thielavioides on Poinsettias

Comparison of Growth of Chalaropsis thielavioides and

Thielaviopsis basicola on Various Media

Comparison of Growth Rates

Effect of $\mathrm{pH}$

Effect of Temperature

Effect of Light on Growth Rates

Results of Pathogenicity Tests

DISCUSSION

This paper is published by authority of the State of Jllinois, IRS Ch. 127, Par. 58.12. It is a contribution from the Section of Botany and Plant Pathology of the Illinois Natural History Survey. Robert S. Perry is a graduate student in the Department of Plant Pathology, University of Illinois, and a Junior Professional Scientist in the Section of Botany and Plant Pathology, Illinois Natural History Survey. 

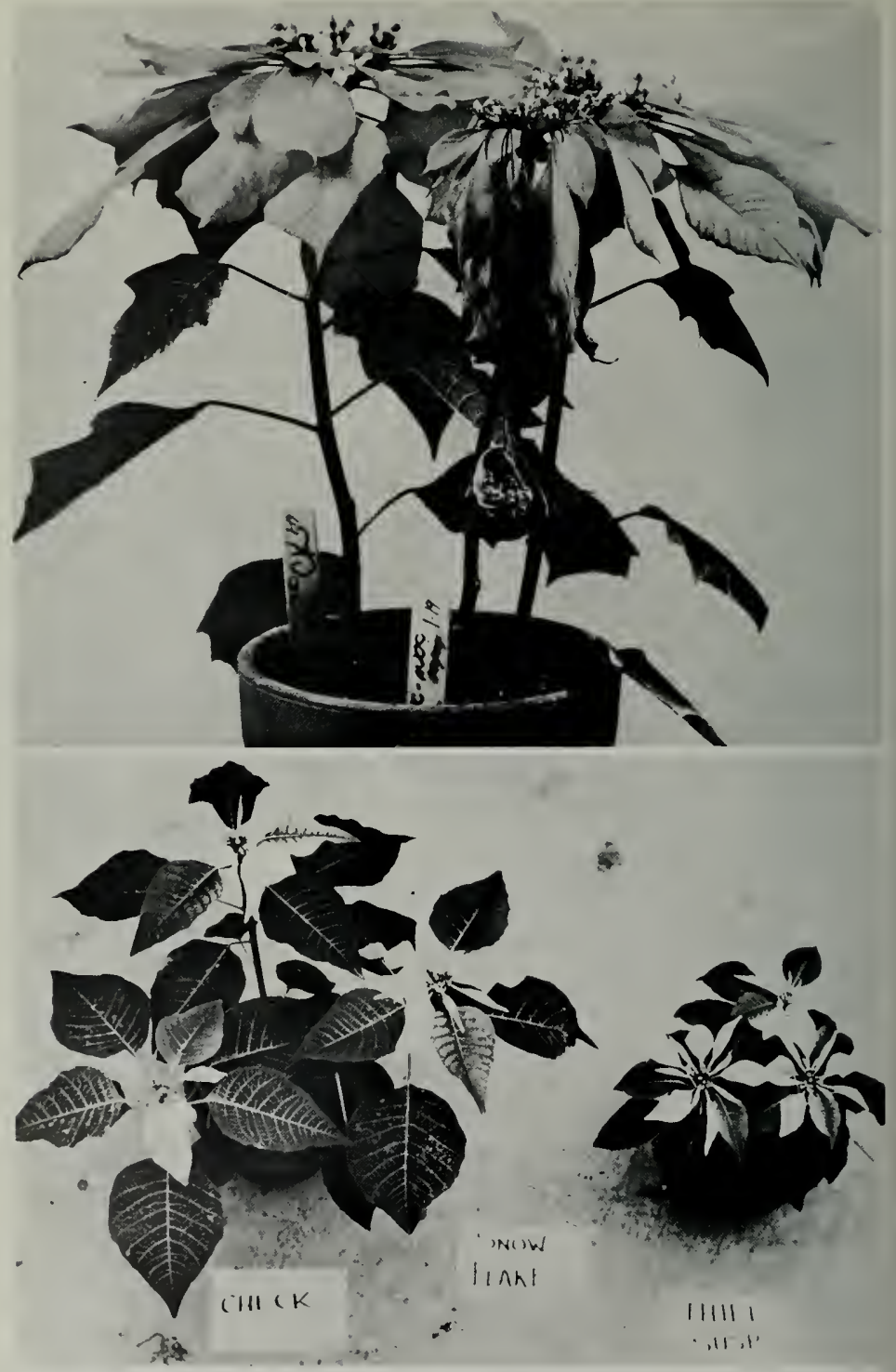

Frontispiece, - Healthy poinsettios and plants showing disease symptoms. In the upper picture the plont in front was inaculated with Thielaviapsis basicala when obout 90 days ald by the stem-incision method. It shows the curling and browning of leaves and the loss of leaves resulting from the disease caused by this fungus. The other plants were not inoculated and remained healthy. In the lower picture the stunted plonts on the right were inoculated with $T$. basicala when about 30 days old by the soil-probe method. The control plants on the left were nat inoculated and show narmal, healthy growth. 


\section{A Comparative Study of Two Components of the Poinsettia Root Rot Complex}

Robert S. Perry

THE MOST 1MPORTANT pathological problem encountered by commercial growers of poinsettias (Euphorbia pulcherrima Willd.) is caused by a complex of fungi composed of Thielaviopsis basicola (Berk. \& Br.) Ferr., Rhizoctonia solani Kuhn, and Pythium ultimum Trow. Collectively these three organisms cause a condition referred to as the poinsettia root rot complex. Each of these fungi is capable of producing a disease, or they may occur in combination, producing a disease complex. $R$. solani and $P$. ultimum generally attack young poinsettia cuttings during the early stages of propagation, and early death usually occurs. Symptoms of the disease caused by $T$. basicola usually appear later in the season, often near poinsettia marketing time, resulting in root deterioration and leaf drop. The presence of symptoms of any of the diseases caused by these fungi is not restricted to a specific phase of the plant's life cycle but may appear anytime. Since the three pathogens involved respond differently to fungicides and environmental conditions, control of this complex is difficult.

$T$. basicola is restricted to attacking the roots of poinsettias, but it is capable of producing infection at almost any point on the roots. An extreme infection may cause the entire root ball to turn black and deteriorate. An advanced symptom of Thielaviopsis root rot is a longitudinal splitting of the stem near the ground line. $P$. ultimum commonly produces infection sites near the root tips and causes extensive root deterioration. In the later stages of the disease caused by this fungus, its effects and those produced by the $T$. basicola disease are indistinguishable. $R$. solani attacks poinsettias either at the ground line or at the transition region between the roots and stem. A ground-line infection usually produces girdling of the stem. An infection at the root-stem transition region usually spreads downward through the root system and results in dead and decaying roots with intact white tips, a condition distinguishable from the other two root rots.

It has been shown that each fungus in this disease complex is strongly influenced by soil temperature (Bateman \& Dimock 1959). Thielaviopsis root rot is favored by the $13^{\circ}$ to $26^{\circ} \mathrm{C}$. and Pythium root rot by the $13^{\circ}$ to $21^{\circ}$ C. temperature range. Although these two diseases are restricted by higher temperatures, Rhizoctonia root rot is favored by the $21^{\circ}$ to $30^{\circ} \mathrm{C}$. range. The temperature ranges favorable to these three pathogens coincide with the temperatures favorable to growing poinsettias. Therefore, poinsettias are susceptible to one or more members of the complex at all temperatures suitable for poinsettia growth.

Soil $\mathrm{pH}$ appears to have as much influence on the development of the disease complex on poinsettias as has temperature. Thielaviopsis (Bateman 1960) and Pythium (Bateman 1962) root rots are most destructive in alkaline, neutral, and slightly acidic soils, but they are considerably restricted in highly acidic soils. Soil $\mathrm{pH}$, however, appears to have little, if any, influence on Rhizoctonia root rot (Bateman 1963).

The diseases caused by these fungi usually have been investigated individually rather than as a complex. Because of the complications involved in working with three pathogens that frequently occur in different population ratios, obtaining consistent, meaning- 
ful data for the complex is difficult. Controls have been found for $P$. ultimum and R. solani (Tompkins \& Middleton 1950; Raabe \& Hurlimann 1970). Although a control has recently been suggested for Thielaviopsis root rot of poinsettias (Manning et al. 1970), a single control for the entire complex has not been found.

Since more research has been conducted on $P$. ultimum and $R$. solani than on $T$. basicola, the present research was originally designed to investigate some of the environmental factors affecting the growth of Thielaviopsis and the development of the root rot caused by it. However, another fungus, Chalaropsis thielavioides Peyronel, frequently was obtained in isolations from diseased greenhouse poinsettias. Since C. thielavioidles had not been reported as being a part of the poinsettia root rot complex, the author decided to investigate its importance as a pathogen on poinsettias. Numerous similarities between $C$. thielavioides and $T$. basicola were evident. The object of this work was to compare the two fungi. Prior to undertaking such a study, the pathogenicity of Chalaropsis on poinsettias had to be established. A comparison of Chalaropsis and two isolates of Thiclaviopsis was made to determine the effects of environment on the growth of the fungi and the ability of the two fungi to produce disease symptoms on poinsettias.

\section{ACKNOWLEDGMENTS}

Much of the work on this project was conducted through the facilities and with the cooperation of the staff of the Illinois Natural History Survey. I would like to express my greatest appreciation for the guidance and assistance offered throughout the project by Dr. J. L. Forsberg, a Plant Pathologist at the Survey. I am also especially grateful to Dr. J. C. Carter, Head of the Section of Botany and Plant Pathology at the Natural History Survey, for his many helpful suggestions and for providing me with laboratory facilities and equipment at the Natural History Survey.

Other members of the Natural History Survey staff who deserve special recognition for making this project successful are Dr. W. A. Hartstirn, Dr. E. B. Himelick, and Dr. J. L. Crane. Dr. Crane was especially helpful in providing assistance in photomicroscopy.

Invaluable contributions in the forms of technical advice and assistance in the propagation of the poinsettias for the host investigations were made by Dr. M. C. Carbonneau, Mr. D. C. Saupe, and Mr. R. C. Chancellor, all members of the Division of Floriculture and Ornamental Horticulture of the University of Illinois. They also provided all of the poinsettia plants, potting materials, and greenhouse facilities used in this study.

I gratefully acknowledge the assistance of Dr. W. M. Bever, Professor of Plant Pathology and Head of Department, University of Illinois; Mrs. Betty A. Nelson; and Mrs. Mary A. Sponsky in the preparation of this report. Richard M. Sheets, Natural History Survey Technical Illustrator, drew the graphs, and Wilmer D. Zehr, Survey Technical Photographer, provided some of the photographs. The paper was edited by Robert M. Zewadski, Associate Technical Editor of the Survey.

\section{LITERATURE REVIEW}

Thielaviopsis basicola (Berk. \& Br.) Ferraris is pathologically important as a member of a root rot complex and as the fungus responsible for the black root rot disease and the internal collar rot disease on more than 120 species of plants in 30 families. $T$. basicola has been reported as a component of a root rot complex on poinsettia (Baker, Davis, \& Thomas 1953; Bateman 1962 and 1963; Bateman \& Dimock 1959; Dimock 1951; Keller 1954; and Keller \& Shanks 1955), citrus (Tsao \& Van Gundy 1962), tobacco (Allison 1938; 
Stover 1950), and cotton (Blank, Leyendecker, \& Nakayama 1953; King \& Presley 1942; Leyendecker 1952; Presley 1947; Sherbakoff 1940; and Staffeldt 1959). T. basicola is known to produce a root and crown rot on phlox (Peterson 1967). Keller \& Potter (1954) have reported that $T$. basicola causes a general root decay of cyclamen, begonia, scindapsus, cineraria, and gerbera. Lloyd \& Lockwood (1961 and 1963) reported this fungus on the roots of peas and beans. Ostazeski (1966) reported the stunting and death of bird's-foot trefoil resulting from rootdeterioration caused by $T$. basicola.

The influence of various environmental factors on the growth of $T$. basicola in culture and the incidence of disease produced by this fungus have been studied extensively. Bateman (1963) suggested that $\mathrm{pH}$ is probably the most influential factor affecting the growth of the pathogen and definitely the most important factor affecting disease development. He reported that Thielaviopsis grew best in a range of $\mathrm{pH} 4.7-5.5$ and that cultural growth was retarded on neutral or alkaline media. All of the reports indicate that Thielaviopsis is favored by a slightly acid condition. Lucas (1955) found $\mathrm{pH}$ to be more influential on the growth of the pathogen in culture than in soils and reported a $\mathrm{pH}$ range of 3.9-6.2 for the two media. Keller (1954) found the optimum $\mathrm{pH}$ range to be 6.2-7.2 for disease development on poinsettias.

Earlier findings by Rawlings (1940) do not agree with Bateman's suggestions on the importance of the $\mathrm{pH}$ factor. Rawlings found $\mathrm{pH}$ to exert little influence on the colony type. He reported that $\mathrm{pH}$ had a greater influence on the amount of growth (based on colony diameter) than on the colony type or components of the colony. Rawlings also stated that growth on basic agars $(\mathrm{pH} 7.0-8.0)$ was greater than growth on acidic agars ( $\mathrm{pH} 4.0-5.0$ ). More chlamydospores were produced on acidic agars than on basic agars.

The effect of temperature on the growth of Thiclaviopsis in culture and on the development of the disease brought about by this organism have been studied by numerous investigators. Lucas (1955) and Tsao \& Van Gundy (1960) reported that the best growth of the fungus in culture occurred at $21^{\circ}$ to $25^{\circ}$ C. Bateman \& Dimock (1959) reported $21^{\circ}$ to $24^{\circ} \mathrm{C}$. the optimum temperatures for growth. King \& Presley (1942) found the best growth to occur at $30^{\circ} \mathrm{C}$., whereas an early report by Rawlings (1940) stated that Thiclaviopsis grew better at $20^{\circ} \mathrm{C}$. than at either $10^{\circ}$ or $30^{\circ} \mathrm{C}$.

Optimum temperatures for disease development are reported to be slightly lower than optimum temperatures for the growth of this fungus in culture. Peterson (1967) declared $16^{\circ}$ to $20^{\circ} \mathrm{C}$. to be the optimum range for the development of the disease. In this temperature range stem lesions developed in 4 weeks. At slightly higher temperatures lesions developed after 8 weeks. Keller \& Shanks (1955) determined the approximate optimum temperature for disease development to be $10^{\circ} \mathrm{C}$. Several researchers have attempted to correlate average soil temperatures with soil types in predicting the incidence of disease (Baker, Davis, \& Thomas 1953; Bateman 1963; Johnson \& Hartman 1919; and Staffeldt 1959). As a result of their work, it is known that certain types of soils are more conducive to Thielariopsis root rot than are others.

There are few reports on frequency of occurrence of Thielaviopsis root rot in a field situation. Presley (1947) reported that in one field of cotton in Mississippi 20 percent of the plants were killed by $T$, basicola.

Reports in the literature concerning the pathogenicity of Chalaropsis thielavioides and the incidence of the disease it causes are scant. This fungus has been reported as a pathogen on the roots of roses (Baker 1953), walnut trees (Hamond 1935), Chinese elms (Wright 1942), agave (De La Isla 1962), and lupine (Longree 1940). In general, Chalaropsis has been reported 
as a fungus that causes the failure of bud and graft unions. Often referred to as the "black mold fungus," Chalaropsis frequently produces a fungal mat over the cut surface of the stock to be used in a graft. The impeding presence of the mycelial mat prevents the successful fusion of the stock and scion. Other accounts contain reports of black mold causing grafting failures on roses (Baker \& Thomas 1946; Longree 1940; and Milbrath 1946). Baker \& Thomas (1946); Lamb, Wright, \& Davidson (1935); Wright (1942); and Hamond (1935) stated that Chalaropsis is a wound parasite.

Studies on the effect of environmental factors are lacking. Baker \& Thomas (1946) reported that the optimum temperature range for growth of Chalaropsis in culture was $18^{\circ}$ to $30^{\circ} \mathrm{C}$.

Boerema (1959) suggested that $C$. thielavioides is an occasional surface contaminant on carrots packaged in perforated polyethylene bags. Lloyd \& Lockwood (1962) reported Chalaropsis to be a common contaminant on packaged carrots. Since carrot slices are used as an isolating medium for obtaining Thielaviopsis from diseased tissues, they warned against mistaking the contaminant Chalaropsis for Thielaviopsis. Longree (1940) reported numerous similarities between Chalaropsis and Thielaviopsis. She prepared a good morphological description of Chalaropsis and compared several of the different isolates reported prior to 1940 .

\section{MATERIALS}

\section{Fungi}

Two isolates of Thielaviopsis basicola were used for testing the effects of environmental factors on the growth and pathogenicity of the fungus. One strain, referred to in this paper as TBT, was obtained from Dr. Peter Tsao of the University of California at Riverside. This culture had been isolated from citrus roots. A second isolate, TBB, was received from Dr. D. F. Bateman of Cornell University. This culture had been isolated from tobacco and was known to be pathogenic on beans also.

A culture of Chalaropsis thielavioides was isolated while attempting to isolate $T$. basicola from diseased poinsettias exhibiting symptoms like those of a Thielaviopsis infection. Stock cultures were made by making single-spore isolations from the original cultures. They were maintained in culture by repeated transfer.

Since $C$. thielavioides has been reported to be a contaminant on packaged carrots (Boerema 1959; Lloyd \& Lockwood 1962), the Chalaropsis may have come from the diseased poinsettia roots or from the carrot slices used as the isolating medium. A check was made on the isolation technique in an attempt to locate the source of the $C$. thielavioides. From every package of carrots used, several sterilized carrot slices were placed in petri dishes. These petri dishes were exposed to the same conditions as were the dishes in which pieces of diseased poinsettia roots had been placed on sterilized carrot slices. Chalaropsis was never found on any of the carrot slices that had not been brought into contact with diseased poinsettia root material. In every instance in which C. thielavioides grew on the carrot slices, a piece of root tissue was present. Consequently, the fungus must have come from the diseased poinsettia roots.

\section{Media}

Several media were used in an attempt to find the most suitable medium for the growth of the two fungi. Commercially prepared Difco media used were lima bean agar, prune agar, malt agar, cabbage infusion agar, commeal agar, Noble agar, and potatodextrose agar. Freshly prepared potatodextrose agar and carrot-dextrose agar were also used in growth tests. Six media were prepared from living poinsettias. These poinsettia media consisted 
of leaf-and-stem-dextrose agar, rootdextrose agar, and entire-plant-dextrose agar. The remaining three were of the same components without the dextrose.

Six flowering poinsettias, each approximately $30 \mathrm{~cm}$ tall, were cut between the upper root and lower stem regions in preparing the root agar and the leaf-and-stem agar. The root sections were first thoroughly washed and then macerated in a Waring Blendor with $400 \mathrm{ml}$ of distilled water for 5 minutes. The macerated material was added to $1,600 \mathrm{ml}$ of distilled warm water in which 40 grams of agar had been dissolved. This volume was then divided into two 1-liter portions. Twenty grams of dextrose were added to one 1-liter portion of the mixture. This medium was autoclaved at $121^{\circ} \mathrm{C}$. for $45 \mathrm{~min}$ utes and then poured into petri dishes. The leaf-and-stem agar was similarly prepared, except that the aboveground portions of six poinsettia plants were used. The entire-plant agar was prepared in the same way, except that the medium contained both the roots and the aboveground portions of the plants.

Two broth cultures were used to test growth on a liquid medium. Potatodextrose broth and V-8 juice broth were made in the same manner as the counterpart agars were made, except that the agar ingredient was omitted. Into 125-ml flasks were poured $100 \mathrm{ml}$ of each broth. The flasks were plugged and sterilized. Seeding was done by dropping fungus plugs into the broth.

\section{Poinsettias}

Nine varieties of poinsettias, Barbara Ecke Supreme, Elisabeth Ecke, Mikkel Pink, Mikkel Dawn, Paul Mikkelsen, Stop Light, Snow Flake, Snow Cap, and Ecke White, varying in flower color from dark red, to pink, to white, were used in establishing and maintaining the pathogenicity of Chalaropsis thielavioides and Thielaviopsis basicola. Six of the varieties were varieties marketed commercially and three were experimental varieties.

\section{METHODS}

\section{Microscopic Examinotions}

Samples of the fungi were obtained by cutting plugs from colonies on agar and by making needle scrapings of diseased host tissues. Microscopic examinations of the fungi were made with a phase microscope. When samples containing only endoconidia were desired, a petri dish containing a fungus colony on agar was flooded with distilled water and slightly agitated. Drops of the liquid containing the spores were then removed from the dish and placed on microscope slides. Needle scrapings of host tissues were placed in drops of lactoplenol on slides. The scrapings were usually composed of both mycelium and spores. Measurements of the fungus structures were made.

\section{$\mathrm{pH}$ Studies}

A $\mathrm{pH}$ range was prepared by altering the components of fresh potatodextrose agar and V-8 juice agar. Two solutions were prepared: a 25 -percent lactic acid solution $(\mathrm{pH} 2.0)$ and a sodium hydroxide solution made by dissolving 4 grams of sodium hydroxide in 1 liter of water $(\mathrm{pH} 12.0)$. A recorded number of drops of these solutions was then added to each of a group of sterilized petri dishes. Basic media were prepared by adding $5,10,15$, or 20 drops of the sodium hydroxide solution to petri dishes, each of which contained $20 \mathrm{ml}$ of liquified potato-dextrose agar or V-8 juice agar. The dishes were swirled to insure uniform distribution of the solution and the media. Readings of the $\mathrm{pH}$ values were taken with a Beckman $\mathrm{pH}$ meter before the seedings and after 10 days of growth. The media, after the addition of the sodium hydroxide solution, varied from pH 5.7 to 9.2 .

The lactic acid solution was added in portions of $1,3,5,8,10$, or 20 drops to dishes containing $20 \mathrm{ml}$ of $\mathrm{V}-8$ juice agar. These media, after the addition of the lactic acid, had a $\mathrm{pH}$ range of 7.12.7. The agars were solidified and the 
dishes then inverted to prevent moisture condensation on the petri dish lids.

Tests on the influence of $\mathrm{pH}$ on the growth of the isolates were made on samples of the two fungi grown on V-8 juice agar and potato-dextrose agar. These groups consisted of the various $\mathrm{pH}$ plates seeded and kept in constant darkness. The plates were maintained in an incubator at a constant $24^{\circ} \mathrm{C}$. Diameters of the colonies were measured every 24 hours for 10 days. Each plate was seeded with a plug approximately $2 \mathrm{~mm}$ square taken from actively growing areas in stock culture plates. Three replicate samples of each isolate were tested at each $\mathrm{pH}$ level.

\section{Temperature Studies}

Seeded plates of standard V-8 juice agar were placed in unlighted incubators set at $5^{\circ}, 10^{\circ}, 15^{\circ}, 20^{\circ}$, and $30^{\circ} \mathrm{C}$. Linear growth was measured directly along a consistent diameter bisect every 24 hours for 13 days. Three plates of each of the three isolates at each temperature were measured.

\section{Light Studies}

Each of six V-8 juice agar plates was seeded with a plug of TBB isolate, six with a plug of TBT isolate, and six with a plug of Chalaropsis. Three plates seeded with TBT, three with TBB, and three with Chalaropsis were placed in an unlighted incubator at $24^{\circ} \mathrm{C}$. The remaining three plates of each isolate were placed at $24^{\circ} \mathrm{C}$. in an incubator lighted by a constant light source of 95 footcandles. Daily measurements of the diameters of the growing colonies were made. Samples were taken from the fungal colonies on the 2 nd, 7 th, 10th, and 14th days of the testing period for microscopic observation.

Placed in each of thirty-six 125-ml flasks were $100 \mathrm{ml}$ of potato-dextrose broth. In another thirty-six 125-ml flasks were placed $100 \mathrm{ml}$ of V-8 juice broth. For each isolate, 12 flasks of potato-dextrose broth and 12 flasks of V-S juice broth were used. Eighteen flasks of each broth type were seeded and wrapped in a double layer of aluminum foil. Nine wrapped flasks of each broth were placed on a 144-revolutions-per-minute shaker. Nine flasks of each broth were seeded, placed on the shaker, and exposed to constant light. The remaining 18 flasks of each broth, 9 wrapped in foil and 9 not covered, were placed in the light but not on the shaker. This experiment was conducted at room temperature. Seedings were made by dropping a 2-mm-square plug from an active colony into the broth. Observations were made every 3 days for 15 days.

\section{Pathogenicity Tests}

Nine varieties of poinsettias were used in testing the pathogenicity of the two fungi. Cuttings were rooted in sand and then were potted in a soil composed of equal portions of sand, loam, and vermiculite. Poinsettias in the vegetative and flowering stages were inoculated. The vegetative poinsettias averaged $20 \mathrm{~cm}$ in height and were growing singly in standard 4-inch pots. The flowering poinsettias varied from 20 to $50 \mathrm{~cm}$ tall. These were grown three plants per three-fourth size, 6 -inch diameter pot (a pan).

All poinsettias were maintained in a greenhouse at the University of Illinois Floriculture and Ornamental Horticulture Division. The air temperatures varied from $16.7^{\circ}$ to $18.3^{\circ} \mathrm{C}$. Soil temperatures varied from $15^{\circ}$ to $18.7^{\circ} \mathrm{C}$. In one brief experiment, the soil temperatures were raised to the $19^{\circ}$ to $25^{\circ}$ C. range by regulating the air temperature. The plants were watered twice daily and fertilized once daily with a mixture of equal parts $(.68 \mathrm{~kg}$, or 1.5 pounds) of ammonium phosphate and potassium phosphate dissolved in 379 liters (100 gallons) of water. Artificial lighting was not used. Shading was used on exceptionally hot days. Most of the pathogenicity tests were conducted during the winter months.

Inocula of each of the three isolates 
were prepared by the following method. Four petri dish colonies of the isolate (including the V-8 juice agar, mycelium, and spores) were added to $I$ liter of sterile, distilled water and blended for 5 minutes in a Waring Blendor.

Three different methods of placing the fungi in contact with the poinsettias were used. In the soil-drench method, the suspensions were poured over the soil surface in portions of $50 \mathrm{ml}$ per plant (or $150 \mathrm{ml}$ per pan). After the suspension had soaked in, $100 \mathrm{ml}$ of distilled water were poured over the soil.

A second method is referred to as the soil probe. Prior to drenching the soil with $50 \mathrm{ml}$ of inoculum as in the soil-drench method, the root balls of the poinsettias were probed six times with a handled scoopula. This probing served to break some of the roots. The soil around the check plants was drenched with $50 \mathrm{ml}$ of sterile distilled water in place of the inoculum.

The third method of placing the fungi in contact with the poinsettias involved digging the soil away from the crown area of the poinsettias. The exposed upper root-lower stem region was washed with sterile water; the surface was disinfested with 75-percent ethanol; and it was rinsed with sterile, distilled water. A sterilized scalpel was used to make a $1-\mathrm{cm}$ slit into the pith region of the stem. From an actively growing agar colony, a mass of fungus mycelium and spores was removed with a sterilized transfer needle and transferred into the slit. The slit was then covered with petroleum jelly and the soil was replaced. The lower stems of the check plants were disinfested with ethanol, slits were made, the slits were covered with petroleum jelly, and the soil was replaced.

The success of the inoculations was determined from disease symptoms exhibited by the plants and recovery of the fungi from the plants. Comparisons with check plants with regard to general vigor, leaf fall, chlorosis, dwarfing, premature flowering, lesions, and reduced root growth were considered in evaluating the intensity of the diseases.

Isolations from diseased roots and lower stem lesions were made to recover the pathogens. Although potato and sweet potato slices and nondiseased poinsettia stems and roots were also tried, Yarwood's carrot-slice isolation technique (Yarwood 19.16) was the only method successfully used in reisolating the pathogens. Packaged carrots were peeled and sliced into discs $40-70 \mathrm{~mm}$ thick. Four of these discs were placed in each sterile petri dish. The dishes were stacked under a bell jar. On top of the stack was placed an open dish containing $10 \mathrm{ml}$ of a gaseous sterilant, propylene oxide (Klarman \& Craig 1960). The bell jar was sealed for 24 hours to maintain the concentration of the propylene oxide. The jar was then removed and the unopened dishes were allowed to air for 24 hours to disperse the propylene oxide. Root balls of poinsettias showing symptoms of disease were opened and infected root segments approximately $1 \mathrm{~cm}$ long were removed. These segments were surface disinfested by placing them in a 5-percent Clorox solution for 2 minutes and then rinsing them in sterile distilled water. The root segments were placed on the sterilized carrot slices in petri dishes, $10 \mathrm{ml}$ of water were added to each dish, and the dishes were kept on a laboratory table. Daily observations were made for the appearance of fungus growth.

\section{RESULTS}

\section{Morphology of Thieloviopsis basicala}

Thielaviopsis basicola produced both reproductive and vegetative stages abundantly in culture as well as on the host. Characteristically, there were two types of vegetative mycelium (Fig. $I B)$. The most common type was hyaline, thin-walled, and septate. The younger hyphae varied from 1.9 to $2.6 \mu$ wide. In culture under favorable 
conditions, ${ }^{1}$ the hyaline mycelium constituted about 90 percent of the vegetative growth and was relatively dense. A second type of mycelium was found in the older areas of the colony, especially in the center, or on the agar surface below the aerial growth. The older hyphae were wider, 2.6-3.9 $\mu$, with dark brown pigmentation.

Both types of mycelia produced spores. The hyaline mycelium produced endoconidiophores in which endoconidia were produced (Fig. 1D). During this investigation, growth under mildly unfavorable conditions resulted in an increase in the amount of thick-walled mycelium. A reduction in the growth of both types of mycelia was caused by intensely unfavorable conditions.

This fungus produced chlamydospores and endoconidia in its reproductive phase. The endoconidia were produced abundantly both on the host and in culture. They were single celled and stoutly cylindrical to barrel shaped with rounded corners (Fig. 1D). The cellular contents appeared to vary with conditions. Under favorable conditions they were composed of a thin, hyaline cell wall enclosing granular contents and two conspicuous vacuoles, one in each end of the cell.

Endoconidial cells produced under unfavorable $\mathrm{pH}$ or temperature conditions appeared to be inconsistent in contents. In some cases the contents appeared to be entirely granular or entirely vacuolated, while in others the two vacuoles appeared to be the sole constituents of the cells.

Aging of the endoconidia produced a slight change in shape. The ends of the individual cells transformed from flattened with rounded corners to semiovoid. During maturation these cells widened slightly, whereas Chalaropsis

'Throughout this paper references to unfavorable conditions indicate $\mathrm{pH}$, temperature, or light conditions, individually or combined, that were not conducive to the best growth of the fungi. Favorable conditions are the $\mathrm{pH}$, temperature, and light requirements indicated by this study as being most conducive to the growth of the two fungi. endoconidia appeared to elongate slightly.

Endoconidia of the $T$. basicola isolate from citrus averaged $7.59 \times 2.37 \mu$ (Table 1). The endoconidia of this isolate varied from 4.56 to $13.11 \mu$ in length and from 2.28 to $2.85 \mu$ in width. Mean dimensions of the endoconidia of the isolate from tobacco were $7.96 \mathrm{x}$ $2.85 \mu$, with a range of $5.20-11.70 \mu$ long and 2.28-3.42 $\mu$ wide. Except for these slight deviations in measurements, the endoconidia from the two isolates were identical. Germ tubes developed from the ends of the cells. In this study germ tubes were not observed developing from the middle region of the cell in either Chalaropsis or Thielaviopsis.

Thielaviopsis endoconidia were indistinguishable from those of Chalaropsis. Generally, the biguttulations of Thielaviopsis endoconidial cells were more prominent, but this characteristic was not sufficiently consistent to permit separation of the two fungi.

Thielaviopsis endoconidia were produced within endoconidiophores similar to those of Chalaropsis. They were composed of tapering terminal cells (phialides) and one to four basal cells. In the isolates of the fungi studied in this investigation, basal cells varied in length from 6.3 to $9.1 \mu$ and averaged $2.6 \mu$ wide. In the Chalaropsis isolate the basal cells of individual endoconidiophores frequently varied slightly in size in such a way that the largest cell was at the end opposite the sporeproducing cell. There was a progressive reduction in size of the remaining cells toward the terminal cell.

In the two isolates of Thielaviopsis this condition occasionally occurred, but usually all of the basal cells were of the same size. This condition made it difficult to distinguish the termini of the hyphae and the origins of the endoconidiophores. However, endoconidiophores arising from short, lateral branches were easy to differentiate. The tapering terminal cells varied in length from 15.6 to $32.4 \mu$. Endoconidiophores 


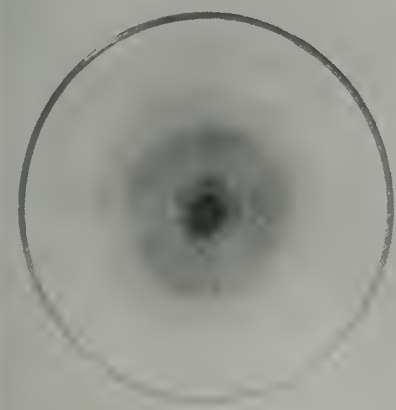

A
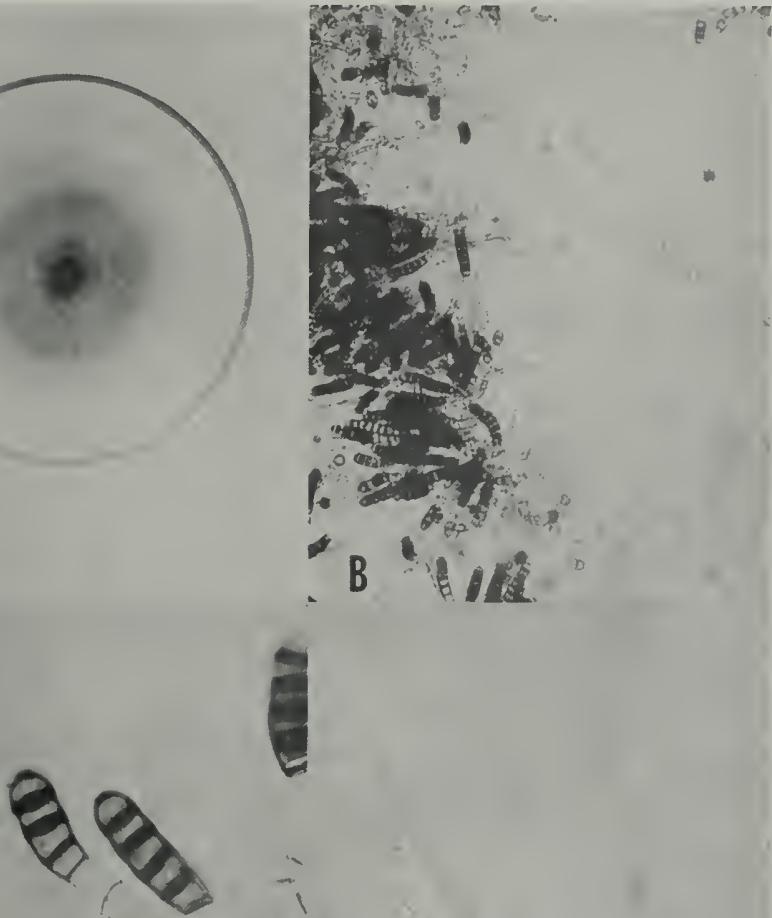
produced conidia individually, several conidial cells in different stages of development could be seen within a single conidiophore. Mature cells were extruded singly from the apex. Conidia not dispersed after expulsion from the terminal cells occasionally created chains by adhering to one another end to end. Chains of conidia containing 15 or more cells were observed.

The thick-walled, dark brown, segmented mycelium produced chlamydospore chains. Most of the thin-walled hyphae remained hyaline and did not change. However, some of this mycelium in certain areas of the colony became dark brown, remained segmented, and developed thick walls. The terminal tips of the thicker hyphae developed into single, hyaline, bulbous cells. Other than the enlarged tip, no apparent specialized structures were observed. As the tip cell became more ovoid to elongately ovoid to club shaped, the walls thickened and the entire structure became darkly pigmented. Cross walls developed as the cell elongated to produce a final structure of two to seven chlamydospores (Fig. 1C).

One hundred chlamydospores and 100 chlamydospore chains of each isolate, TBT and TBB, were measured (Table 1). Chlamydospore chains of the TBT isolate averaged $20.4 \times 5.8 \mu$. The largest chain measured $28.3 \mathrm{x}$ $7.27 \mu$ and contained seven spores. The smallest chain measured 17.1 x $5.7 \mu$ and consisted of four spores. The mean length of an individual spore was $4.41 \mu$.

Chlamydospore chains of the TBB isolate averaged $18.2 \times 5.7 \mu$. The largest chlamydospore chain measured 26.0 × $6.5 \mu$ and was composed of six spores. The smallest measured $13.0 \mathrm{x}$ $4.8 \mu$ and was composed of three spores. The individual spores averaged $3.99 \mu$ in length.

Chlamydospore chains were produced at the ends of long strands of hyphae. Clusters of chlamydospore chains were the result of clusters of hyphal strands rather than the branching of a single 
strand. Mature chlamydospore chains were released from the parent mycelium by fragmentation. The chlamydospore chains were released intact with a short fragment of hypha still attached to the basal cell.

Some controversy has developed among plant pathologists over the germination of Thiclaviopsis chlamydospores. Christias \& Baker (1967) reported that before germ tubes could develop, the individual spores comprising the chain had to be separated. Each spore was then believed capable of germination. Their work appeared to demonstrate the function of chitimase in breaking the spores apart so that germination could take place. However, Papavizas \& Adams (1969) later demonstrated that intact chlamydospore chains, as well as individual chlamydospores, were capable of germination. They found that the breaking up of chlamydospore chains into individual spores by chitinase was not a necessary prelude to germination. I did not study the germination of chlamydospores. There is no record of a necessary maturation or resting period before germination of Thielaviopsis chlamydospores as has been noted in Chalaropsis chlamydospores (Longree 1940).

\section{Colany Characteristics of $T$. basicola}

Observations were made and data were recorded on the development of Thielaviopsis basicola colonies on V-8 juice agar and potato-dextrose agar. More extensive development of vegetative and reproductive structures occurred on V-8 juice agar. Growth of $T$. basicola on V-8 juice agar was luxuriant but slow. A 15-16 day growth period under favorable conditions was required for both of the isolates studied to completely cover the agar surface in a $90-\mathrm{mm}$ diameter petri dish. However, measurable growth was recorded 2 days after seeding.

The first growth appeared as hyaline, vegetative hyphae radiating outward from the point of seeding. Throughout the development of the colony, the outermost perimeter was composed of these hyaline, nonsporulating hyphae appressed to the agar surface. On the 4th day after seeding, aerial, hyaline mycelia began to be produced around the seeding point and to develop progressively outward. By the 5th day after seeding, endoconidiophores and endoconidia could be found in the aerial hyphae.

Within the next 48 hours the hyphae around the seeding plug began to darken. Microscopic examinations of the fungus in this region revealed that the darkening was brought about by the production of darkly pigmented, thickwalled hyphae. These dark strands predominated the fungal mass but remained close to the agar surface. Pigmentation appeared to vary between dark gray to black and golden brown. Pigmentation did not appear to be consistent with the isolate, as both isolates produced both color types but not within the same colony.

The dark, thick-walled hyphae gave rise to the terminal chlamydospore chains. The chlamydospores were also thick-walled and darkly pigmented in colors corresponding to those of the hyphae from which they had developed. As chlamydospore production continued to increase, endoconidial production decreased.

A fully developed colony consisted of a series of concentric circles of visible differences in growth type (Fig. 1A). The innermost region around the point of seeding was a mass of compacted, semi-aerial, dark-walled hyphae. Thickwalled, dark hyphae and chlamydospore chains composed approximately 95 percent of the fungus material in this region, but occasional hyaline hyphae were found. This center region, about 10 percent of the entire colony area, had a black, matted appearance. The next growth ring constituted about 40 percent of the colony area and was composed of approximately 75 percent dark hyphae and chlamydospore chains 
and 25 percent hyaline hyphae and endoconidia. Because of the presence of fewer dark liyphae in relation to the mass of hyaline hyphae and the more aerial nature of the hyaline hyphae, this region had a gray, wool-like appearance.

In the remaining concentric growth patterns, the percentages of dark hyphae and chlamydospore chains comprising the fungal colony decreased progressively as the distance from the point of seeding increased. The proportion of hyaline hypliae and endoconidia increased progressively as the distance from the seeding point increased. Apparently no standard number of concentric growth rings made up a colony. Common borders between the growth rings were not sharp and well defined but were transition zones gradually integrating one ring with the next. Additional characteristics of typical $T$. basicola colonies observed during this study were consistent with those described by Johnson \& Valleau (1935).

\section{T. basicolo on Poinsettias}

Thielaviopsis endoconidia were found on almost all external surfaces of diseased areas on poinsettias. Abundant endoconidia were found on decaying root segments, in lesions on lower stems, and on the inner walls of the lower pith cavities of the stem. These spores were always found on the external or internal surfaces but never embedded within the host tissue. As did those of Chalaropsis, the thin-walled, hyaline hyphae ramified within the infected host tissue. Endoconidiophores developed from the hyaline hyphae that were either on the surface of the host or embedded in the diseased tissues. Endoconidial production seemed to be influenced little by environmental factors or host conditions. Endoconidia were found either on or within the host on internal surfaces at any time when symptoms of Thielaviopsis infection were present.

Thiclaviopsis chlamydospores were produced much less frequently on the host than were the endoconidia. However, the Thiclaviopsis chlamydospores were found more frequently on the host than were Chalaropsis chlamydospores. Chlamydospore production of Thielaviopsis seemed to be related to environmental conditions and the development of the disease. The development of longitudinal lesions on the lower stems of the poinsettia host was a symptom of an advanced stage of Thielaviopsis infection. Chlamydospores were found in these lesions. During my investigation, chlamydospores were detected only within the stem lesions, probably because chlamydospore production required light. Masses of thick-walled, darkly pigmented hyphae with multispored, terminal chlamydospore chains developed within these lesions.

\section{Morphology of Chalaropsis thielavioides}

The vegetative stage of Chalaropsis thiclavioides consisted of septate hyphae that varied in width from 1.2 to $2.6 \mu$. In culture most of the hyphae were thin and hyaline. As they aged, the cells became slightly wider, and the walls darkened. The reproductive structures were produced on this type of mycelium. Even under favorable conditions the mycelia were sparse. Most of the growth consisted of endoconidiophores arising from the older hyphae. Under unfavorable conditions the mycelia became even more sparse than that produced under normal conditions. The darkening of the mycelium as it aged varied inversely with the intensity of the unfavorable conditions. Under highly unfavorable conditions the mycelium failed to darken and remained thin walled, and vacuoles predominated the segmental contents. The hyphal cells sometimes enlarged to produce beadlike strands of mycelium.

This fungus produced two types of asexual spores, endoconidia and chlamydospores (Fig. $2 B$ ). The endoconidia were produced within endoconidiophores (Fig. 2D), each composed of two or three basal cells and a spore-producing cell (phialide). The basal cells varied from 6.5 to $9.1 \mu$ in length and were about $2.6 \mu$ wide. The spore-pro- 


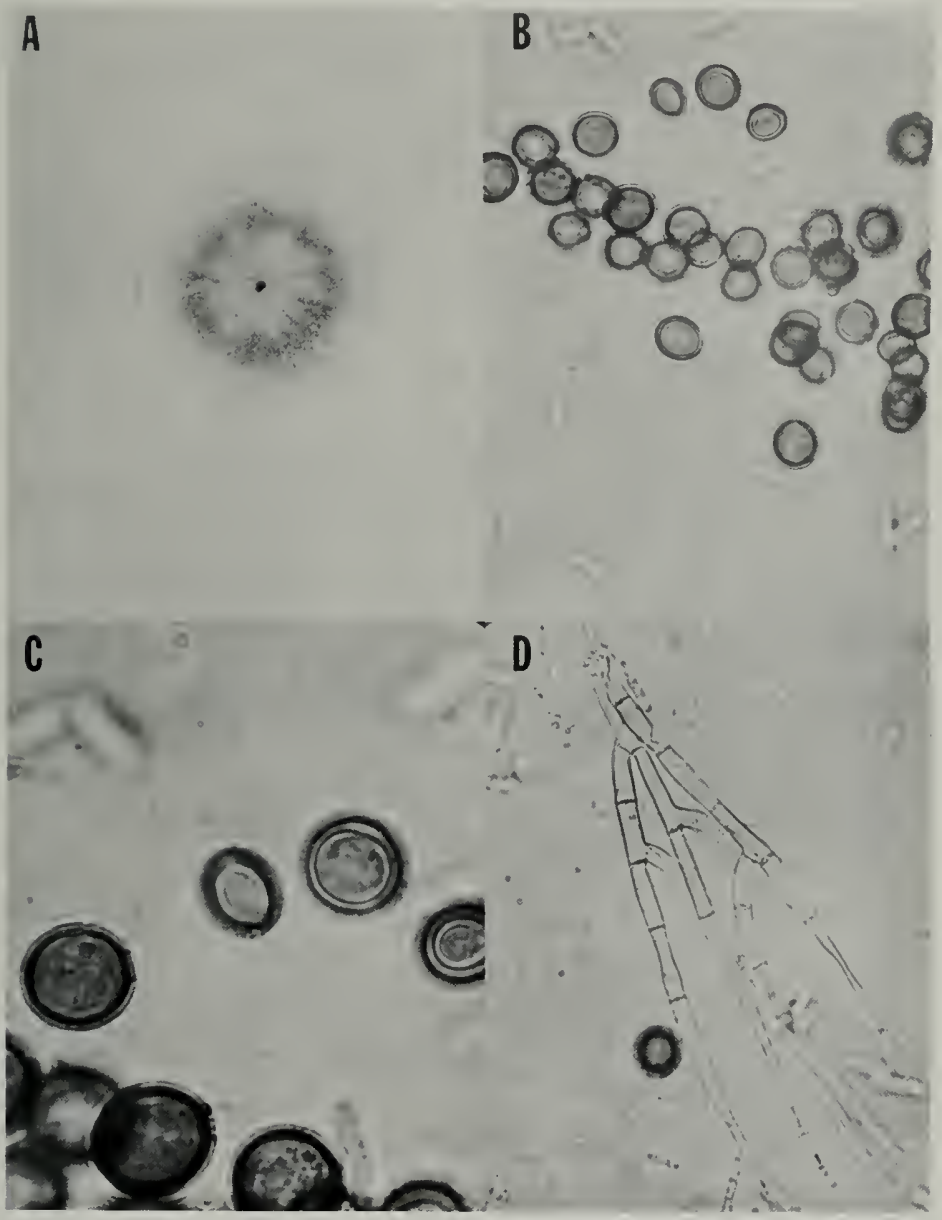

Fig. 2. - Choloropsis thielovioides: A, 10-doy-old colony on V-8 juice ogor; $B$, components of o typicol colony (X 520); C, chlomydospores (X 1235); $D$, endoconidiophores with endoconidio (X 520).

ducing terminal cell varied from 11.7 to $27.3 \mu$ in length. The tapered phialides produced endoconidia singly. Although several endoconidia in various stages of formation were seen within a terminal cell, the mature endoconidia were extruded from the apex individually. A stubby side branch occasionally developed from a mature strand of mycelium. One to five endoconidiophores developed from this branch. It was not uncommon to see several conidiophores on one lateral branch (Fig. $2 D$ ).

The endoconidia of $C$. thielavioides 


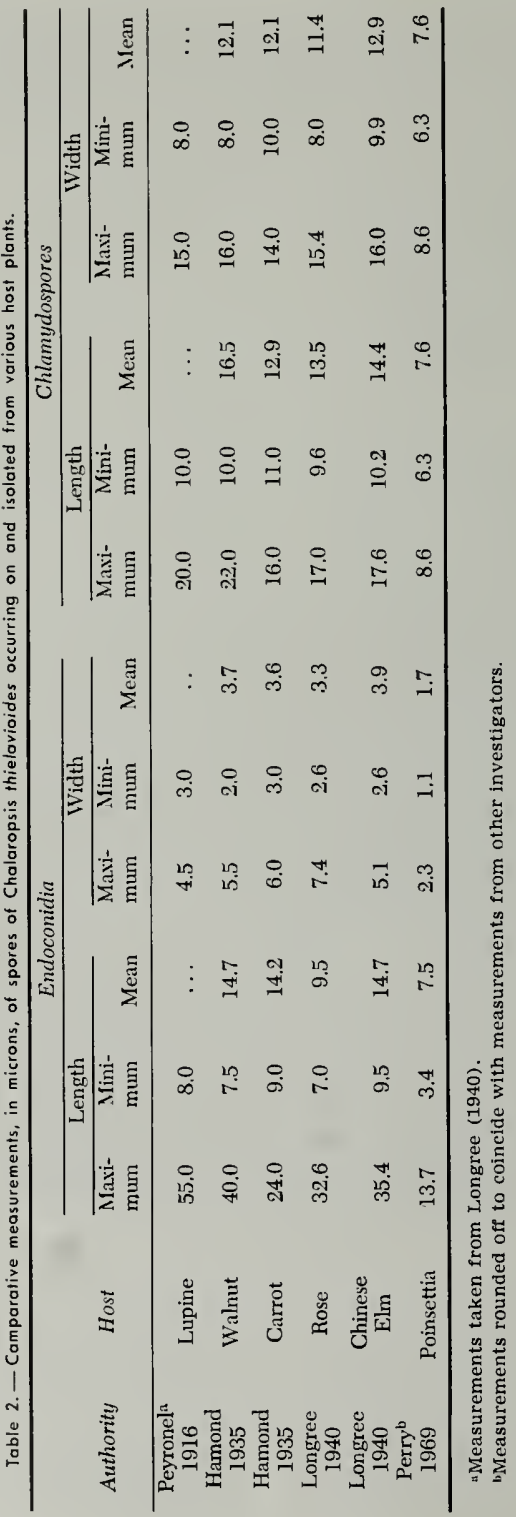


were produced in great abundance on the host and in culture. These cells were found clinging together in chaíns of a dozen cells or more. Endoconidia germinated at any time after they were released from the conidiophores. Germ tubes were produced from the ends or the sides of the spores. Individual endoconidia were hyaline and biguttulate. They were barrel-shaped to cylindrical with rounded comers. As these cells aged, the ends became slightly more rounded. The endoconidia varied from 3.42 to $13.68 \mu$ long and $1.14-2.28 \mu$ wide, with mean dimensions of $7.50 \mathrm{x}$ $1.67 \mu$. The endoconidia of minimal dimensions were almost always found in chains. Spore measurements of the isolate used in this work and the spore measurements of isolates used by other workers are compared in Table 2.

A second type of asexual spore, the chlamydospore (Fig. 2C), was produced in fewer numbers than were the endoconidia. Longree (1940) referred to these as macroconidia. These cells were produced only in the older parts of a colony. Short lateral branches developed from cells of the older, pigmented mycelium. The tips of these lateral branches and the terminal tips of the hyphae became bulbous. Longree (1940) reported that macroconidia and macroconidiophores were frequently found clustered at the base of an endoconidiophore. In my investigations 1 did not find this condition. Macroconidia from the $C$. thielavioides used in this work were always produced individually and not at the bases of endoconidiophores.

Maturing chlamydospores were thin walled and hyaline for a short while, but soon became thick walled and darkly pigmented. The mature chlamydospores were subglobose to ovoid with small flattened bases. Mature chlamydospores were freed from the colony without any portions of the conidiophores still attached to them. Spores freed shortly before maturity often still had a short fragment of conidiophore attached. Freed, hyaline chlamydospores sometimes had a fragment of conidiophore equal in length to several times their diameters.

The diameter of the chlamydospore varied with the isolate. Mature chlamydospores from the isolate used in this investigation were spherical, with a mean diameter of $7.64 \mu$. They varied from 6.27 to $8.55 \mu$ in diameter. As indicated by the data in Table 2, other reports of this fungus show the chlamydospores to be more ovoid than spherical.

These spores did not germinate readily. None of the chlamydospores observed showed any evidence of germination. However, the cultures were not maintained for more than a month. Longree (1940) stated that the macroconidia either require a resting period or mature slowly. She found that 2-month-old macroconidia germinated poorly, whereas the percentage of germination was greater in 3-monthold spores. Chlamydospores were produced only after the mycelium had reached a certain stage of maturity or when the mycelium was subjected to unfavorable conditions.

\section{Colony Characteristics of $C$. thielavioides}

Chalaropsis thielavioides grows luxuriantly on only a few agar media. Although it does grow on most common agars, the fungus sporulates abundantly and produces an extensive colony on only a few. Good growth was produced on V-S juice-dextrose-yeast extract agar (Fig. 2A), but even this growth was slow. On V-S juice agar Chalaropsis covered the agar surface in a $90-\mathrm{mm}$ diameter petri dish in 10-12 days under favorable conditions. If a plug of agar with fungal spores and mycelium was placed on agar in a petri dish, measurable growth was observed after 2 days. This first growth appeared as nonsporulating hyphal strands living on or slightly below the agar surface. The vanguard of hyaline mycelia continued outward, preceding the subsequent 
colonial development. If a single point of seeding was made on the agar, a circular colony was almost always prodiced.

For the first ferv days the colony appeared hyaline, and then it began to whiten. The change to white was brought about by the production of endoconidiophores and endoconidia. These reproductive structures grew with a concentric perimeter slightly (about $5 \mathrm{~mm}$ ) within the enlarging hyaline perimeter. After 5-6 days of growth under favorable conditions, Chalaropsis produced a colony that covered about two-thirds of a $90-\mathrm{mm}$ diameter petri dish. By this time a small, circular halo immediately surrounding the initial plug had turned black. This blackened area consisted of developing and mature chlamydospores. The mycelium was almost entirely on the surface of the agar or slightly submerged, and it was pigmented a golden brown. The black color in the colony was due to the dark-brown-to-black pigmentation of the numerous chlamydospores. Although the mycelium in the chlamydospore area remained on the surface, the surrounding mycelium became more aerial and fluffy. This caused the center area to appear sunken in the white mycelium. After 8-10 days a light gray area constituting about one-half of the colony began to appear in the center of the colony. The gray color was due to the intermingling of maturing chlamydospores and the accompanying abundant endoconidia.

The fully developed colony appeared as a series of progressively lighter colored, concentric circles. The innermost circle, about one-tenth of the total area, was black; sunken; and composed of many chlamydospores, few endoconidia, and much thick-walled mycelium.

The next zone was fluffy and whitish gray and accounted for about one-half of the colony area. This area consisted of abundant endoconidia, much thinwalled mycelium, and abundant chlamydospores. When this area was scraped from the agar and the surface of the agar was examined, a dark surface growth of thick-walled mycelium was seen radiating outward from the center. This surface growth appeared to terminate after enlarging to about onehalf of the area of the entire colony. Chlamydospores which grew up through the aerial endoconidial mycelium and caused the graying of this region were produced from this growth.

The next outermost circle was white and, although definitely aerial, not quite as fluffy as the adjacent, inner region. This white area constituted about onethird of the colony and was composed almost entirely of endoconidia, endoconidophores, and thin-walled hyphae. The surface growth below this region frequently was grayish and contained few chlamydospores.

The outermost concentric region made up about one-tenth of the total area. It consisted entirely of surface and subsurface, hyaline, thin-walled hyphae with no spores of either type. Under ideal conditions, the margin of the colony was regular. Abnormal or adverse conditions frequently produced lobed or irregular margins. A 10-dayold Chalaropsis colony on V-8 juice agar grown under favorable conditions is shown in Fig. $2 A$.

\section{C. thielavioides on Poinsettios}

Signs of Chalaropsis were more difficult to find on the poinsettia plant than were signs of Thielaviopsis. Chalaropsis endoconidia were found in moderate numbers on the external surfaces of the diseased areas of the roots. These spores were also found externally in the areas of the stem where bark had been loosened or sloughed off near the ground line. All of the mycelium produced within the infected host tissues was thin walled and hyaline. This mycelium was difficult to locate in the decaying tissues. It appeared to produce endoconidiophores that protruded through the epidermis of the host tissue and extruded the endoconidia externally.

Chlamydospores of Chalaropsis were 
not produced abundantly on poinsettias. Environmental conditions or host influence may have been responsible for the lack of abundant chlamydospores. Chlamydospores from the isolate used in this experiment were found only in the pitl cavities of the lower stem region of the host. These spores appeared to be restricted to the lowest pith chamber, since they were not found in the upper chambers of the stem. Thick-walled, darkly pigmented hyphae developed on the walls and septations of the lowest chamber. Individual terminal chlamydospores were produced from the thick-walled hyphae. No chlamydospores were found embedded in the host tissues, on diseased roots, or on any diseased surface exposed to light. Light may have been the critical factor that determined the location of Chalaropsis chlamydospore production.

\section{Comparison of Growth of Chalaropsis thielavioides and Thielaviopsis basicala on Various Media}

Various media were tested to determine the one most satisfactory for culturing the three isolates. Of the media tested, V-S juice agar was the most satisfactory. Prepared as suggested by Miller (1955), this agar had a $\mathrm{pH}$ range of $7.0-7.25$. Both fungi produced vegetative and reproductive structures abundantly on this medium.

Both fungi grew and sporulated equally well on carrot-dextrose agar and V-S juice agar, but the carrot-dextrose agar was not used because of its more involved method of preparation. V-8 juice can be easily purchased, whereas carrot juice is not so readily available. A juice was easier to use in the media preparation than macerated carrot tissue.

Potato-dextrose agar was not as satisfactory as the V- 8 juice agar. Hyaline mycelia and endoconidia were produced on potato-dextrose agar, but chlamydospores and dark hyphae were produced infrequently and sporadically. Colonies of both fungi on potato-dextrose agar were sparse and usually occurred be- low the surface or appressed to the surface.

Testing of the poinsettia agars proved interesting but not too beneficial. No growth was made by either fungus on agar derived from poinsettia tops only, either with or without dextrose. Growth of Thielaviopsis on agar derived from the entire poinsettia plants was poor. This growth consisted of light gray, random mycelia on the agar surface. Sporulation did not occur. Chalaropsis produced a sparse, aerial mycelium with some endoconidia. Again, the presence or absence of dextrose had little effect. All three isolates grew well on the poinsettia-roots-only agar. Both types of vegetative and reproductive structures were produced abundantly. Growth of all three isolates was noticeably better on the dextrose-supplemented agar. Fungal growth on these two media was comparable to growth on V-S juice agar. The poinsettia-roots medium was not used, however, because of the extra time and effort required in its preparation.

Growth on lima bean agar, prune agar, malt agar, cabbage infusion agar, cornmeal agar, and Noble agar was negligible. Of all the agars tested, only potato-dextrose agar and V-8 juice agar were used in subsequent experiments.

Two liquid media were tested. Potatodextrose broth and V-S juice broth supported good growth of both fungi. Chalaropsis produced a complete surface mat in 7 days on V-S juice broth. Thielaviopsis produced a complete mat in 10 days. Both fungi failed to produce a complete mat on potato-dextrose broth.

Neither fungus produced any growth in either of the two broths in shake cultures.

\section{Comparison of Growth Rates}

Daily measurement of the colonial enlargement of the three isolates indicated that Chalaropsis was the fastest growing. The colony increased at the rate of $8.0 \mathrm{~mm}$ in diameter per day. The colony produced was dense and 
contained both coarse and fine hyphae as well as both types of spores.

The colonies of both isolates of Thielaviopsis increased $5.9 \mathrm{~mm}$ in diameter daily. This fungus grows somewhat slower than Chalaropsis. The colonies produced were similar to those produced by Chalaropsis. They were dense and contained both types of hyphae and both types of spores. The rate of growth of each isolate is shown graphically in Fig. 5.

\section{Effect of $\mathrm{pH}$}

Although temperature influenced the amount of growth, $\mathrm{pH}$ influenced the type of growth of the fungi reported on here. Conspicuous variations in the morphology of the fungi accompanied variations in the $\mathrm{pH}$ of the media. Fig. 3 shows the effect of $\mathrm{pH}$ on colony growth.

C. thielavioides had a narrower favorable $\mathrm{pH}$ range than either isolate of $T$. basicola. $C$. thielavioides produced some growth at $\mathrm{pH} 3.9$ and fair growth at $\mathrm{pH}$ 9.2. In my opinion, based on the amount of growth and quality of the colony, the optimum $\mathrm{pH}$ range for Chalaropsis was 6.7-8.0 (Fig. 3A). Although colonies on agars with a $\mathrm{pH}$ in excess of 8.0 produced normal daily colonial enlargement, the hyaline hyphae were distorted in shape and the endoconidia were nearly oval. An increase in $\mathrm{pH}$ to above 8.0 produced an intensification of the distortions. Chlamydospores and dark hyphae were sparse or absent in all colonies on agar with a $\mathrm{pH}$ greater than 8.0. Colonies on agars with a pH between 8.0 and 8.7 were appressed to the agar surface. Colonies on agars with a $\mathrm{pH}$ higher than 8.7 were almost entirely submerged and definitely hyaline.

Chalaropsis grew better on basic agar than on acid agar. Although the growth of reproductive and vegetative structures was retarded on agars in the lower $\mathrm{pH}$ range, the deforming of structures was not as extensive as it was on the basic agars. Growth was reduced on agars with a $\mathrm{pH}$ of less than 7.0.
Colonies varied from dark gray at $\mathrm{pH}$ 6.8 to whitish gray at $\mathrm{pH} 3.8$. On none of the acidic agars did the colonies appear hyaline. Their color was due to the dark, thick-walled hyphae intermingled with some hyaline hyphae and endoconidia. At the lower end of the $\mathrm{pH}$ range, there were fewer chlamydospores. The colony produced at $\mathrm{pH}$ 3.8 contained occasional thick-walled hyphae but no chlamydospores. An abundance of endoconidiophores was responsible for the whitish color of this colony.

The type of growth also varied as $\mathrm{pH}$ values varied. A decrease in $\mathrm{pH}$ produced an increase in the mass of aerial hyphae. Colonies on highly acidic agars appeared fluffy in comparison with the wooly colonies grown at $\mathrm{pH} 7.0$.

Variations in $\mathrm{pH}$ influenced the growth of isolate TBT more than that of isolate TBB. Neither isolate grew at a $\mathrm{pH}$ lower than 3.2. Although the basic limit was not defined, a progressive decline in the growth and formation of typical structures of the colonies at $\mathrm{pH}$ 9.0 indicated that the maximum was somewhere near that point. As Fig. $3 C$ shows, after 10 days of growth the diameters of TBB colonies on agars with various $\mathrm{pH}$ values ranged from 18 to $62 \mathrm{~mm}$. A variation of $27-74 \mathrm{~mm}$ in the diameters of the TBT isolate colonies occurred on these agars (Fig. $3 B$ ). The optimum for both isolates was between $\mathrm{pH} 5.9$ and 6.7. The colonies on agars outside of the optimum $\mathrm{pH}$ range produced more vegetative structures than reproductive structures.

TBB and TBT colonies on agars within the optimum $\mathrm{pH}$ range were white for the first 2-3 days, due to the abundant production of thin-walled hyphae and endoconidiophores. After several days the colony, except for a narrow white perimeter, developed shades of gray. The gray color resulted from the production of chlamydospores and thick-walled hyphae. Daily diameter enlargement varied between 5.8 and 7.4 $\mathrm{mm}$.

Morphologically, the colonies on the 
more basic media tended to be light gray to whitish. As the basic condition was intensified, chlamydospore production was lessened and endoconidial production became greater. At $\mathrm{pH} 8.0$ the colonies of both isolates consisted almost entirely of masses of endoconidiophores with few other structures. These colonies were characterized by alternate rings of dense and sparse masses of endoconidiophores. Occasionally chlamydospores and some dark hyphae were
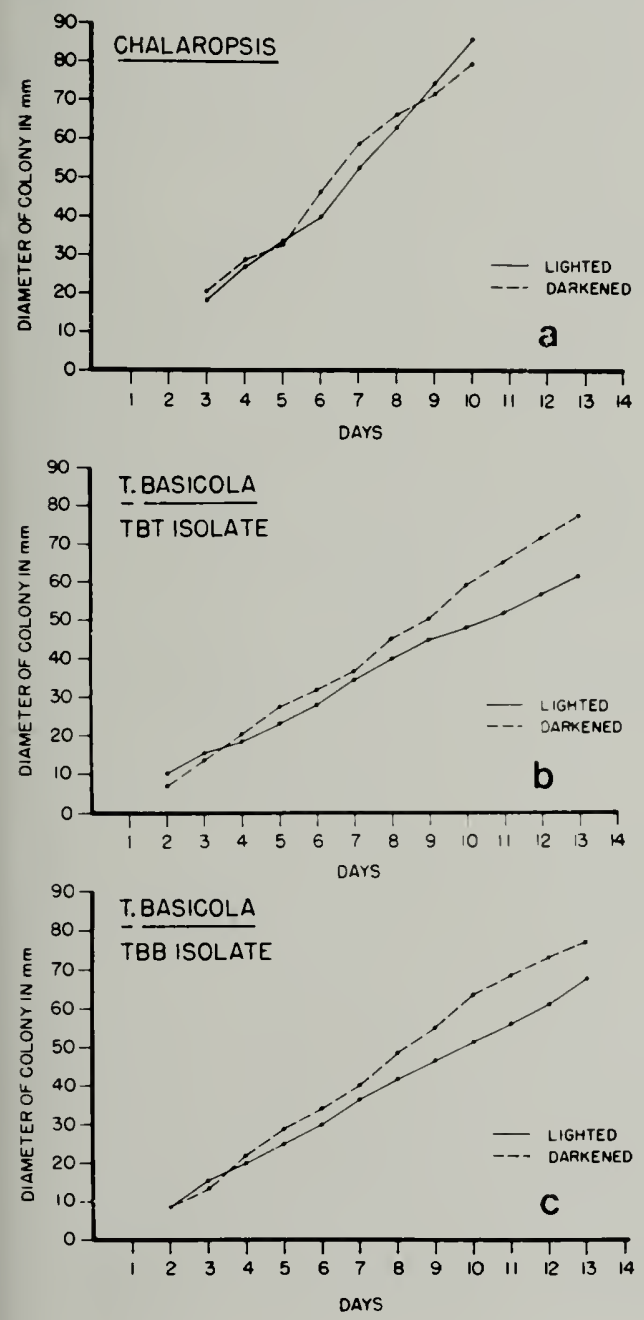

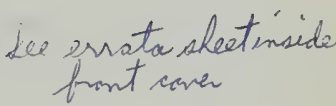

Fig. 3. - The effect of variotions in $\mathrm{pH}$ and medium type upon the growth of: $A$, Chalaropsis thielaviaides; $B$, the TBT isolate of Thielariapsis basicala; $C$, the TRB isolate of $T$. basicola. 
observed in rindom clumps, usually within the denser mycelial circles. Colonies of both isolates of Thiclaviopsis on agar with a $\mathrm{pH}$ value of 8.6 were composed almost entirely of hyaline hyphae appressed to the agar surface. A few endoconidia were present. Each colony on agar more basic than pH S.6 consisted only of thin, distorted, hyaline hyphae embedded in the agar. The daily diameter growth of the colonies growing on media with $\mathrm{pH}$ values above 6.7 varied from 3.6 to $6.5 \mathrm{~mm}$.

Acid media induced the formation of a different type of colony. Each colony on an acid agar was composed mainly of aerial mycelium. Concentric circles within the colony were produced on agars with $\mathrm{pH}$ values of $7.0-4.5$. However, the mycelium in each of these circles was black to intermediate gray. Growth on media with a $\mathrm{pH}$ as low as 4.5 resulted in an increase in the production of chlamydospores. This increase produced a corresponding darkening of the colonies to almost entirely black.

Colonies of both isolates grown on agars in the $\mathrm{pH}$ range $4.5-4.1$ were lighter in color than colonies on slightly less acidic agars. Chlamydospores and dark hyphae were produced in clumps. They were not produced on strongly acidic agars. No chlamydospores were produced on agars with $\mathrm{pH} 3.7$ or below. Fluffiness (or the amount of the aerial mycelium) increased as the $\mathrm{pH}$ of the agar decreased down to $\mathrm{pH} 3.7$. Colonies on the $\mathrm{pH} 3.7$ agar were almost entirely aerial and composed of elongated strands of hyaline hyphae. A few endoconidia and endoconidiophores were found. Colonies on these highly acidified agars were dense enough to form visible margins. These margins were characteristically reticulately lobed. Margins of colonies produced on the highly basic agars were characteristically smooth. Daily increases in diameters of the colonies on acid media varied from 1.8 to $6.2 \mathrm{~mm}$. Both isolates of Thielaviopsis failed to grow on agars with a $\mathrm{pH}$ of 3.2 or lower.
The effect of fungus growth on the $\mathrm{pH}$ of the media was not determined. Before the agar plates were seeded, the $\mathrm{pH}$ was adjusted by adding a predetermined number of drops of acid or base solution to the liquified media. After the 10-day testing period, the media were remelted and tested for $\mathrm{pH}$ with a $\mathrm{pH}$ meter. The changes in $\mathrm{pH}$ of most media were so slight as to be negligible. Fluctuations that may have taken place during the 10 -day period were not determined.

\section{Effect of Temperature}

Temperature exerted an effect on the rate of growth but not on the type of growth of the fungi reported on here. In all tests where temperature did not severely restrict growth, the three isolates produced colonies characterized by a dense composite of both types of hyphae and both types of spores. The only variation was in the diameters of the colonies.

As shown in Fig. $4 A$, the greatest amount of growth of Chalaropsis occurred at $30^{\circ} \mathrm{C}$. Daily enlargement of colonies growing at this temperature varied between 6.4 and $8.5 \mathrm{~mm}$. An abrupt decrease in growth at $35^{\circ} \mathrm{C}$. resulted from the thermal death of many mycelial cells. Although growth at $10^{\circ}$ C. was slight, it was measurable and averaged about $1.2 \mathrm{~mm}$ per day. Growth was evident at $5^{\circ} \mathrm{C}$; ; however, it was restricted to the seed plug and too limited to be measured.

The optimum temperature for growth of both isolates of Thielaviopsis was $25^{\circ}$ C. (Fig. $4 B$ and $C$ ). The TBB isolate grew slightly better at $30^{\circ} \mathrm{C}$. than did the TBT isolate. Colonies maintained at $20^{\circ} \mathrm{C}$. and $15^{\circ} \mathrm{C}$. produced both types of spores and both types of hyphac but were smaller than the colonies grown at $25^{\circ} \mathrm{C}$. The TBT isolate produced no growth at either $5^{\circ} \mathrm{C}$. or $10^{\circ} \mathrm{C}$. TBB, however, produced visible growth at $10^{\circ} \mathrm{C}$., but it was confined to the seed plug and was too limited to be measured. This isolate produced no growth at $5^{\circ} \mathrm{C}$. 

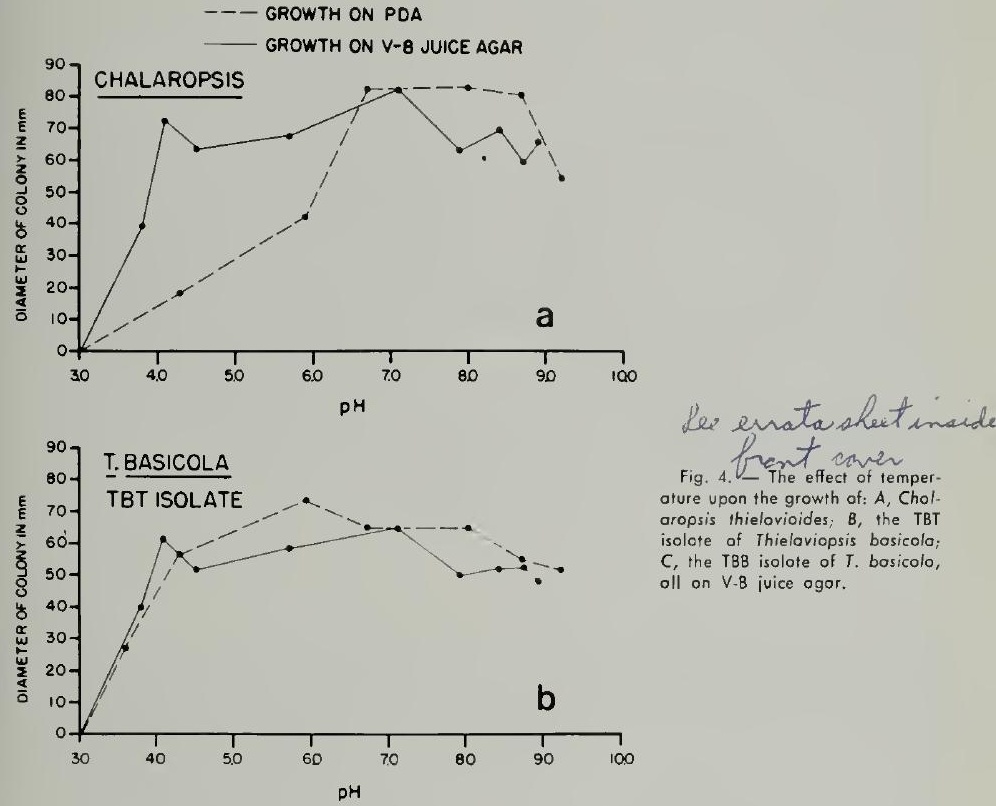

Fig. 4. - The effect of temperature upon the growth of: $A, C$ holaropsis thielovioides; $B$, the TBT isolote of Thielaviopsis bosicola; $C$, the TBB isolote of $T$. basicolo, oll on V-B juice ogor.

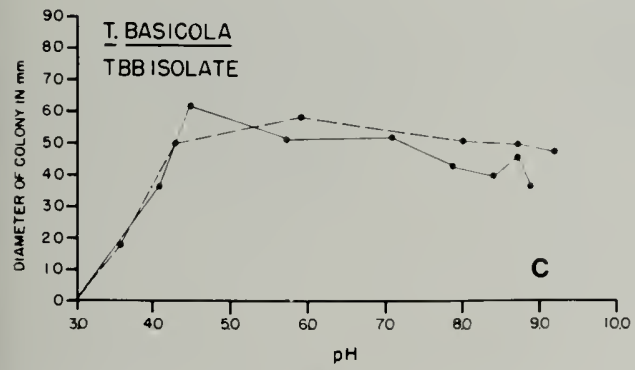

\section{Effect of Light on Growth Rates}

As shown in Fig. 5A, Chalaropsis grew slightly more rapidly in the light than in the dark. While the growth of the colony in the light averaged $8.6 \mathrm{~mm}$ in diameter per day for a 10 -day period, the growth of the colony in the dark averaged only $8.0 \mathrm{~mm}$ per day. During the first half of the test period, growth in the dark slightly exceeded growth in the light. Numerous chlamydospores were produced in the dark after 7-10 days, after which mycelial growth was retarded (Fig. 6). Since few chlamydospores were produced in the light, mycelial production was not noticeably retarded. Microscopic examination of the colonies after 14 days revealed that the colony grown in the light consisted mainly of hyaline hyphae and endoconidia. The colony grown in the dark 
bee ensta shector

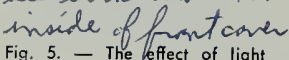

Fig. 5. - The leffect of light upon the growth of: $A$, Chalaropsis thielavioides; $B$, the TBT isolote of Thieloviopsis bosicolo; C, the TBB isolote of T. basicola, oll on $V .8$ juice ogor.
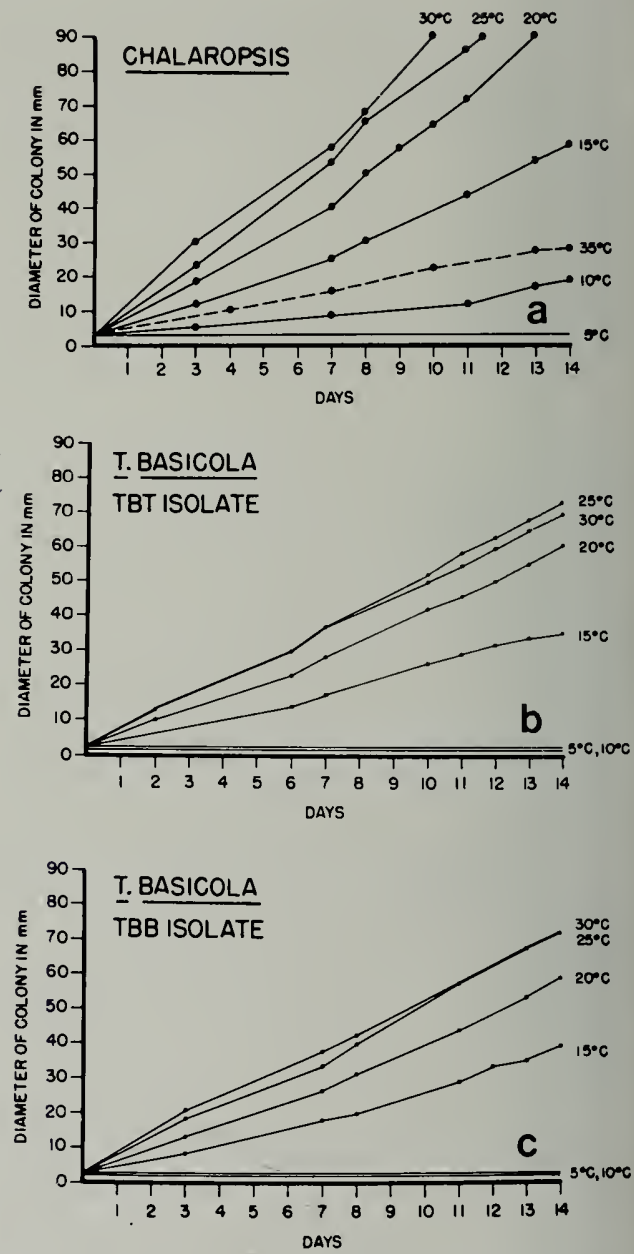

was generally darker gray and composed of thick-walled, dark hyphae and chlamydospores as well as hyaline hyphae and endoconidia.

Both of the Thielaviopsis isolates produced more growth in the dark than in the light (Fig. 7). The TBB isolate averaged $5.9 \mathrm{~mm}$ of diameter growth per day in the dark and $5.2 \mathrm{~mm}$ per day in the light. As Fig. $5 \mathrm{C}$ shows, growth in the dark was consistently greater than growth in the light. Production of chlamydospores and darkwalled hyphae seemed to be favored by light. Fourteen-day-old colonies grown in the light contained many more chlamydospores and dark hyphae than the colonies grown in the dark. These 

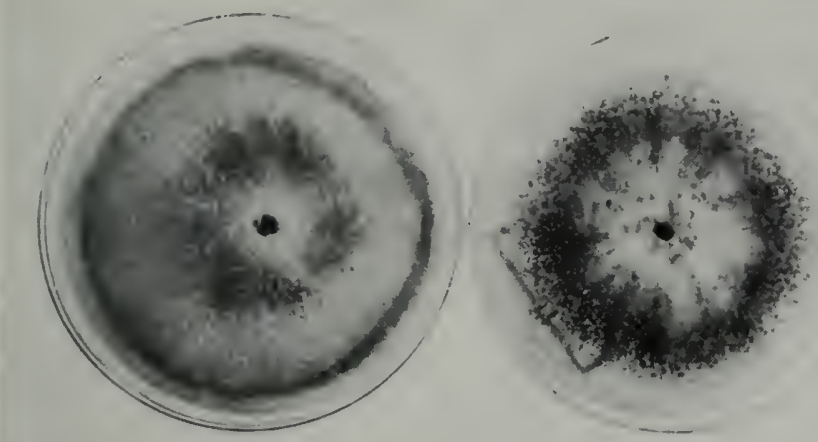

Fig. 6. - The effect of light on colony development of Choloropsis thielovioides grown on V-8 juice ogor. The colony on the left wos exposed to constont light for 14 doys, while the colony on the right wos mointoined in the dork for the some period.
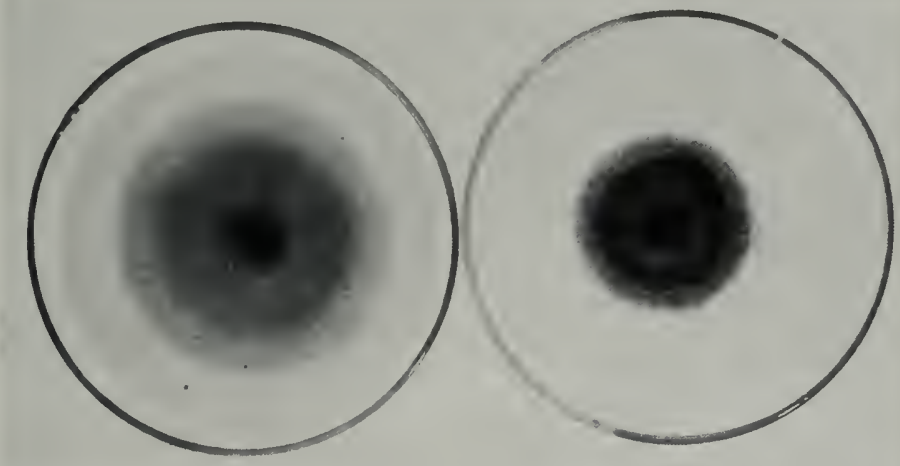

Lee enata a heet an mande of frant cons

Fig. 7. - The effect of light on colony development of Thieloviopsis bosicolo grown on V-8 juice ogor. The colony on the left wos exposed to constont light for 14 doys, while the colony on the right was mointained in the dork for the same period.

two structures were evident in the 2 . to-3-day-old lighted colonies, which produced chlamydospores and dark hyphae throughout the test period. The Thielaviopsis colonies produced under light were dark gray to black; the colonies produced in the dark varied from dark gray through light gray to whitish.
Colony color, morphology, and other characteristics of TBT and TBB isolates of $T$. basicola grown in the light were almost identical, as were the characteristics of the same isolates grown in the dark. Apparently the reaction to light is a characteristic of the fungus rather than of the individual isolates. Like the 
TBB isolate, the TBT isolate averaged $5.9 \mathrm{~mm}$ of daily diameter growth in an unlighted situation. Light appeared to be more influential in retarding the growth of TBT than in slowing that of TBB. The diameter growth of TBT cultures in the light averaged only 4.7 $\mathrm{mm}$ per day. The average rates of growth of these colonies are shown in Fig. $5 B$.

Colony components, growth rate, and growth type of the $T$. basicola isolates when grown on liquid media in the light were comparable to those produced on agar media in the light. Likewise, the colonies grown on liquid media in the dark were similar to those grown on agar media in the dark. Although direct measurements of growth were not made, daily observations and frequent microscopic examinations were used to observe the development of the isolates. Growth on lighted and unlighted potato-dextrose broth was not as profuse as growth on V-8 juice broth. Chalaropsis produced more chlamydospores and thick-walled hyphae in unlighted cultures. Both isolates of Thielaviopsis produced abundant chlamydospores and thick-walled hyphae in the lighted cultures. In all cases the three isolates produced limited amounts of hyaline hyphae and endoconidia within the liquid and profuse amounts on the surface. The production of chlamydospores and dark hyphae was limited to the surface mat.

\section{Results of Pathogenicity Tests}

Evaluations of the success of the infection tests were based on these criteria: (i) production of external and internal disease symptoms on or in the host plants, (ii) microscopic confirmation of the presence of fungal pathogens, and (iii) reisolation of the fungus from the poinsettias. As shown in Fig. 8, the stem-incision inoculation method was the most efficient in producing infection. The host-parasite relationship created by this method resulted in external symptoms on the aerial portions of the host and various amounts of root decay.
The soil-probe and soil-drench methods of introducing the pathogen into the root enviromment resulted in the production of disease symptoms on a small percentage of host plants. The results are based on 10 separate inoculation attempts, each performed at different times but under similar conditions. Twenty poinsettia plants were used each time.

Infection from direct introduction of Chalaropsis thielavioides into the host plant through an incision resulted in external symptoms in 78 percent of the plants inoculated while in the vegetative stage. External symptoms were not pronounced and did not develop immediately. The most common symptom was general chlorosis and stunting that became evident only when comparisons were made with the check plants (Fig. $9 A$ ). Epinastic and curling leaves (Fig. $9 B$ ) were frequent symptoms that indicated root disorders. A general reduction in the sizes of the root balls of the inoculated plants was evident upon removing the diseased plants from the soil (Fig. 9C). In a few cases decaying roots and roots with small lesions were found. The inner surface of the lowest pith chamber of the stem (the inoculation site) was blackened and soft (Fig. 9D).

External symptoms were not produced on poinsettias inoculated while in the flowering stage. Occasionally a small area of diseased tissue was found on the inner surface of the inoculated pith chamber of the flowering plants, but these areas failed to become extensive.

Microscopic examinations of scrapings of the inner surfaces of the stems of plants inoculated in the vegetative stage revealed an abundance of chlamydospores, endoconidia, and mycelium of Chalaropsis in the decaying host tissue. Chalaropsis was cultured consistently from the diseased inner surfaces of the pith chambers.

Quite similar results were obtained when the Thielaviopsis isolates were used in stem-incision inoculations. The 


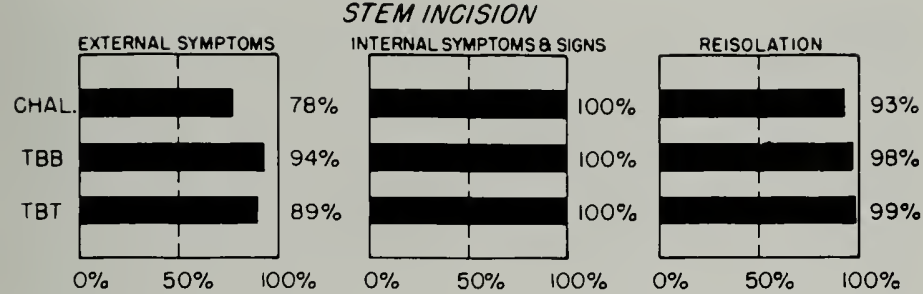

SOIL PROBE
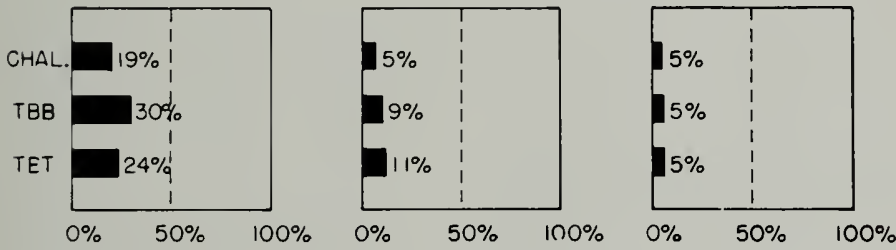

\section{SOIL DRENCH}
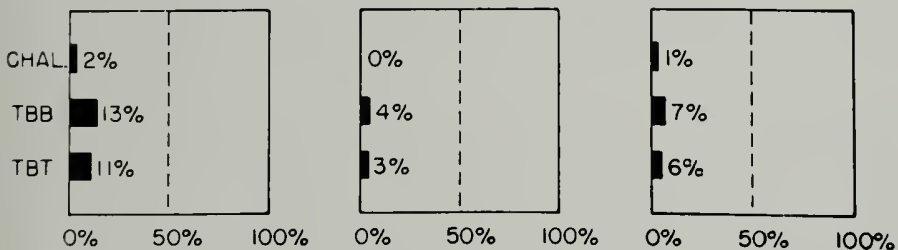

Fig. 8. - A comparison of the disease incidence resulting from three methads of initiating host-pathogen assaciation.

TBB isolate produced external symptoms on 94 percent and the TBT isolate on 89 percent of the plants inoculated in the vegetative stage.

Two groups of symptoms developed on poinsettias that had Thielaviopsis introduced into stem incisions while the plants were in the vegetative stage. One group of symptoms appeared soon after the fungus had been implanted, but the other group did not appear until the plants flowered. Soon after the fungus was introduced, many of the plants became stunted and chlorotic (Fig. 10A), but many others appeared healthy and exhibited no external symptoms until the time of flowering. The presence or absence of external symptoms appeared to vary with the poinsettia varieties. At approximately the time the upper bracts of the poinsettias began to change color, the lower leaves of the inoculated 


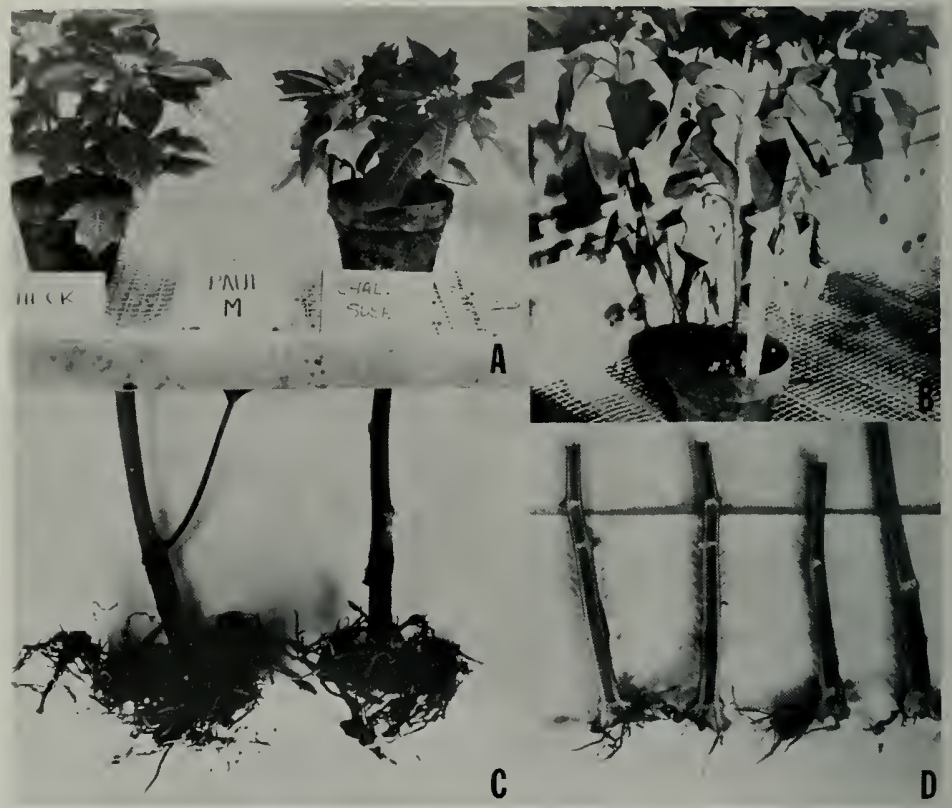

Fig. 9. - Symptoms of Choloropsis root rot on poinsettios: A, stunting of a diseosed 120-doy-old plont (right) compared to o heolthy 120-doy-old plont (left); B, wilting of leoves from notural infection on a 110-day. old plant; $C$, slightly reduced root boll of diseosed plont on right ond normol-sized root boll of heolthy plont on left; $D$, stem with check incision (left) ond stem with incision inoculotion (right).

plants began to fall. Leaf fall was progressive, beginning with the lowest leaves and working upward until only the flower bracts were left at the tips of naked stems (Fig. 10B). Occasionally wilting preceded leaf fall, but often unwilted leaves were dropped. The root ball was reduced in size. Numerous blackened and decaying roots were conspicuous within the root balls (Fig. 10C). Longitudinal sections of the inoculated stems, crowns, and upper root areas of the poinsettias revealed general internal decay throughout the region adjacent to the inoculation slit (Fig. 10D). Endoconidia and hyphae were in the stem lesions and on the outer surfaces of the root lesions. Thielaviopsis was isolated from the diseased tissues around the inoculation lesions of most plants. However, the symptoms discussed here did not develop on the plants inoculated while in the flowering stage.

The soil-probe method of placing Chalaropsis in contact with the poinsettia roots resulted in symptom production on 19 percent of the plants tested. Stunting and chlorosis became evident only after $30-45$ days.

Root decay was more extensive on the vegetative poinsettias than on the flowering poinsettias inoculated by the soil-probe method. The aerial portions of flowering poinsettias did not show disease symptoms. Typical symptoms resulting from inoculations by the soilprobe method were extensive root decay and lack of new root development. Reisolation of Chalaropsis from 
the diseased roots was occasionally successful, but interference from soil contaminants usually prevented successful reisolations.

The application of both isolates of Thielaviopsis to the roots of poinsettias by the soil-probe method resulted in symptoms slightly different from those produced by Chalaropsis. Of the plants that had a soil-probe application of the TBB isolate 30 percent developed external symptoms, and of those receiving an application of the TBT isolate 24 percent developed such symptoms.

No symptoms were produced by Thielaviopsis on the aerial parts of poinsettias inoculated while in the flowering stage. Vegetative poinsettias inoculated by applying Thielaviopsis to probed soil became slightly chlorotic and stunted within 30-60 days. Infected poinsettias also began to flower 7-10 days earlier than did healthy plants.
Lesions began to develop on the crown area of the stem after about 30 days. The outer epidermis and cuticle around the lesion loosened and sloughed off. This was followed by the formation of additional lesions, loosening of the epidermis, and production of callus tissue around the lower stem. Numerous chlamydospores were produced in the lesions. The destruction of roots was extensive. Small areas on the roots or root stubs became discolored and soft. The decay progressed up the root, and in time the entire root became a dark, slimy mass. Endoconidia and hyphae were produced in great abundance on the decaying roots. The entire root balls of most diseased plants decayed and only the lower stem was left in the soil. In such cases the poinsettias usually toppled and died. The amount of disease that developed in a heavily infected greenhouse crop was similar to the re-
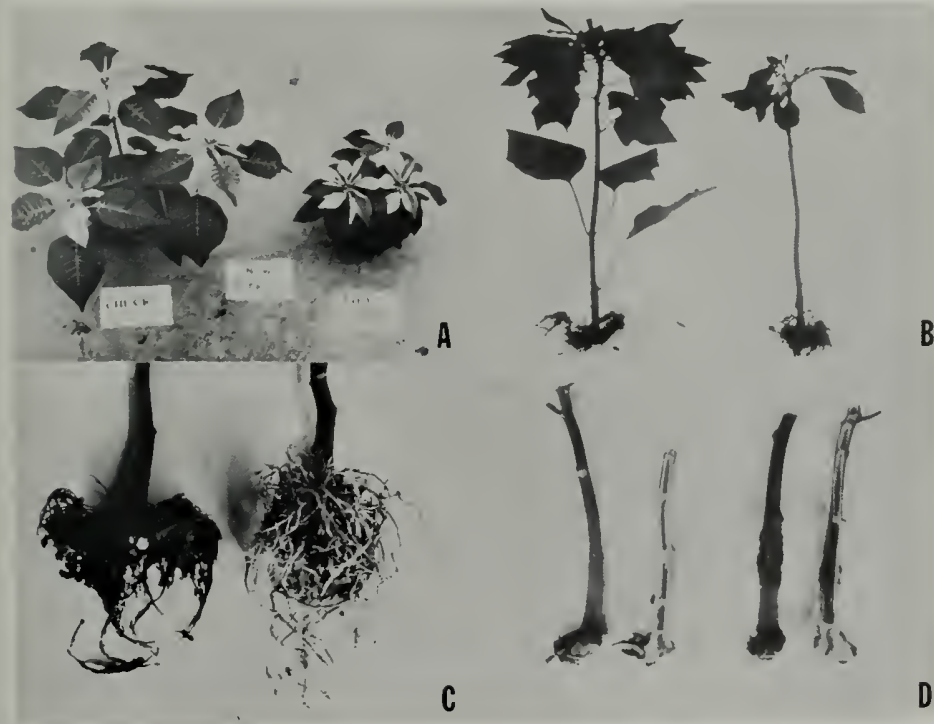

Fig. 10. - Symptams af Thielaviapsis raat rat on painsettias: A, stunted 120-day-ald plant (right) and a healthy plant; B, leaf drap and stunting of a diseased 95-day-ald plant (right) and a healthy 95-day-ald plant (left); C, raat balls af painsettias - diseased raats an left and healthy anes an right; $D$, stem with check incisian (left) and stem with incision inaculation (right). 
sults reported by Presley (1947) on the amount of disease in a field situation.

Reisolation from the decaying roots was successful in the few cases in which soil contaminants did not overrun the Thielaviopsis colonies.

The introduction of Chalaropsis into the poinsettia root environment by the soil-drench method resulted in only slight disease incidence. Symptoms were slight and hardly detectable. Only 2 percent of the inoculated plants appeared slightly chlorotic or stunted or had diseased roots. In a few cases Chalaropsis was reisolated, but soil contaminants usually overran the Chalaropsis. For every 100 poinsettia plants growing in soils infested with the TBB isolate, 13 developed disease symptoms. Many roots of the diseased plants became decayed and new roots did not develop. The TBT isolate applied in a soil drench produced similar results, but on only 11 percent of the treated plants. As with the previous inoculation method, attempts to reisolate both fungi were usually unsuccessful because of faster growing soil contaminants.

\section{DISCUSSION}

The results of pathogenicity tests conducted during this study have shown that Chalaropsis thielavioides is a weak pathogen on poinsettias. This fungus is probably not capable of producing its own infection site. However, it is capable of producing disease symptoms on poinsettias after it has entered a plant through wounds. Pathogenicity studies performed during this investigation suggest that poinsettias with intact roots grown under normal conditions will probably not exhibit a high incidence of disease from this fungus even in soil with large concentrations of Chalaropsis propagules. The amount of wounding proportionally increases the degree of disease incidence. An abnormal number of broken roots, which might result from rough handling during transplanting or intense watering, may appreciably increase losses from the disease caused by $C$. thielavioides. More extensive root breakage from heavy infestations of insects or from inserting stakes in pots could result in extreme disease losses. Although the death of a few secondary roots from insufficient watering might not directly affect the plant, such a condition could provide entry sites for Chalaropsis.

Thielaviopsis is not restricted to entering poinsettias through wounds. Studies show that this fungus can produce an appreciable amount of disease in poinsettias without wounds. However, wounding increases the probability of disease.

Results of some of the cultural studies suggest that environmental conditions may also influence the amount of disease caused by Chalaropsis and Thielaviopsis. A pH range of about 6.0 8.0 and temperatures from about $20^{\circ}$ to $30^{\circ}$ C. were most favorable for growth of both fungi in culture. Similar $\mathrm{pH}$ and temperature conditions in the soil should result in good development and vigorous growth of the fungi. Since these conditions are not ideal for the growth of poinsettias, the combination of weakened hosts and vigorously growing pathogens should result in a greater disease incidence than would normally be expected.

No work was planned as a part of this investigation to test the effect of variations in soil temperatures on disease development. However, one related experiment did produce the anticipated results. The greenhouse air temperature was increased by $6^{\circ} \mathrm{C}$. to induce vigorous flower production. This increase produced a corresponding increase in soil temperature. Using various poinsettia varieties, 150 rooted cuttings were potted in the warmer soils. The soil-probe method was used to inoculate 50 plants with Chalaropsis and 50 with Thielaviopsis; 50 were injected with distilled water. After 60 days, not a single plant had become diseased. This experiment indicated that increased soil temperatures may reduce 
disease incidence by inhibiting fungal development. These results support the findings of Blank et al. (1953) in their work on Thielaviopsis root rot of cotton.

Light enhances the production of chlamydospores in Thielaviopsis and discourages their formation in Chalaropsis. An advanced symptom of Thielaviopsis infection is the formation of ground-line lesions in which chlamydospores are found in abundance. Although chlamydospores are occasionally found on diseased roots, their presence there is minor when compared with their presence in the exposed lesions. Colonies of Thielaviopsis grown in the light contained multitudes of chlamydospores, while colonies grown in the dark contained far fewer. Since all other factors were equal, the conclusion may be drawn that Thielaviopsis chlamydospore production is enhanced by, although not dependent on, the presence of light.

Chalaropsis produced symptoms different from those produced by Thielaviopsis. Although advanced Chalaropsis disease symptoms consisted of groundline lesions and areas of sloughed-off epidermal tissues, chlamydospores were not found in these areas but rather on the internal surfaces of the same areas. In culture, Chalaropsis chlamydospores were found abundantly in colonies grown in the dark but seldom in colonies grown in the light. These results prove that chlamydospore production in Chalaropsis is favored by darkness.

Results of reisolation attempts prove that the development of Chalaropsis and Thielaviopsis in poinsettias is restricted to the tissues not containing chlorophyll. Attempts to reisolate the fungi from all parts of diseased poinsettias showed that both fungi grow only in the roots and in the ground-line stem region of the more mature plants. In no instance was either fungus isolated from leaves or upper stems. These results were anticipated after finding no growth of either fungus on the agar made from the aerial structures of poinsettias and poor growth on the agar made from the entire plant. Apparently there is an unknown factor in the chlorophyll-containing tissues that does not exist in the other tissues and that prohibits the growth of Chalaropsis and Thielaviopsis.

\section{SUMMARY}

Poinsettias are subject to root rots that are caused by three fungi, Thielaviopsis basicola, Rhizoctonia solani, and Pythium ultimum, occurring either individually or in complexes. Infection by these fungi may result in stunting, leaf drop, premature flowering, dwarfed flowers, stem lesions, and occasionally the death of the root. Another fungus, Chalaropsis thielavioides, which has not previously been considered a member of the poinsettia root rot complex, was frequently obtained while attempting to isolate $T$. basicola. Instead, C. thielavioides has been considered to be a surface saprophyte on roots of many plants, especially carrots. There are few reports of it as a plant pathogen. During an investigation of Thielaviopsis root rot, $C$. thielavioides was repeatedly isolated from the roots of diseased poinsettias exhibiting Thielaviopsis-like symptoms. This led to the concept that Chalaropsis should be included as part of the root rot complex.

Some of the major characteristics of Thielaviopsis basicola and Chalaropsis thielavioides are presented for comparison in Table 3.

Two isolates of Thielaviopsis basicola and one isolate of Chalaropsis thielavioides were selected for comparison in cultural requirements, morphology, and pathogenicity. Nine varieties of poinsettias were used to determine and maintain the pathogenicity of the three fungal isolates. Various media were used to determine the $\mathrm{pH}$ requirements and the most suitable culture medium for each of the isolates.

Colony characteristics and morphology were compared for each of the iso- 
lates grown in culture. The isolates were grown at six different temperatures to ascertain the optimum temperature for growing each in culture. Media comprising a $\mathrm{pH}$ range of 2.7-9.2 were used to determine the optimum $\mathrm{pH}$ requirement for each isolate. Cultures of each of the three isolates were grown on several different media both in the light and in the dark to compare the morphological features and growth rates of each isolate under both conditions. Three methods of placing the pathogen in contact with the host were used to determine the pathogenicity of each isolate.

Morphologically, the two fungi compared were similar except for the pro-

Toble 3. - Some of the mojor charocteristics of Thielaviopsis bosicola and Chalorapsis thielavioides.

\begin{tabular}{|c|c|}
\hline Characteristic & Thielaviopsis basicola \\
\hline Disease produced & Root rot \\
\hline Hosts & Numerous herbaceous plants \\
\hline $\begin{array}{l}\text { General disease } \\
\text { symptoms on } \\
\text { poinsettias }\end{array}$ & $\begin{array}{l}\text { Chlorosis, stunting, small root } \\
\text { balls, leaf drop, premature } \\
\text { flowering }\end{array}$ \\
\hline $\begin{array}{l}\text { Advanced disease } \\
\text { symptoms on } \\
\text { poinsettias }\end{array}$ & $\begin{array}{l}\text { Longitudinal lesions on stem } \\
\text { near ground line, girdling of } \\
\text { stem, death of host }\end{array}$ \\
\hline Pathogenicity & Strongly pathogenic \\
\hline \multicolumn{2}{|l|}{ Morphology } \\
\hline Mycelium & $\begin{array}{l}\text { Mostly thin walled and hyaline; } \\
\text { some thick walled and dark }\end{array}$ \\
\hline Endoconidia & $\begin{array}{l}\text { Stontly cylindrical, hyaline, } \\
\text { single celled; average } \\
\text { measurements: } 7.78 \times 2.61 \mu\end{array}$ \\
\hline Chlamydospores & $\begin{array}{l}\text { Dark, multispored chains, } \\
\text { terminal; average measure- } \\
\text { ments: } 19.30 \times 5.77 \mu \text {; club- } \\
\text { shaped chains; unit breaks up } \\
\text { into individual spores; no } \\
\text { resting period required } \\
\text { before germination }\end{array}$ \\
\hline
\end{tabular}

Chalaropsis thielavioides

Root rot, grafting failure

Relatively few herbaceous plants, some trees and shrubs

Chlorosis, stunting, small root balls

Internal decay of stem near ground line

Weakly pathogenic

Mostly thin walled and hyaline; some thick walled and dark

Cylindrical, hyaline, single celled; average measurements: $7.6 \times 1.7 \mu$

Dark, single spores, terminal; average measurements: $7.64 \times 7.64 \mu$; round unit remains intact; resting period required before germination

Optimum range: $\mathrm{pH} 6.7-8.0$

Optimum range: $20^{\circ}$ to $30^{\circ} \mathrm{C}$.

Most growth in the light

Average $8.0 \mathrm{~mm}$ in diameter per day

Requires a wound for entry

Capable of producing its own infection site

Mycelium ramifies host tissue; endoconidia on external and internal surfaces of lower stem and roots

In stem lesions near ground line

With no root damage: 12 percent

With some root damage: 27 percent
Mycelium ramifies host tissue; endoconidia on external and internal surfaces of lower stem and roots

On internal surfaces of lower pith chambers of stem

With no root damage:

2 percent

With some root damage:

19 percent 
duction of chlamydospores. Chlamydospores of Thielaviopsis were produced in club-shaped chains composed of three to seven spores. Chalaropsis chlamydospores were spherical and were produced individually.

Light enhanced the formation of chlamydospores in Thielaviopsis and inhibited their formation in Chalaropsis. An advanced symptom of Thiclaviopsis infection was the formation of groundline lesions in which chlamydospores were found in abundance. Culture colonies of Thiclaviopsis grown in the light contained multitudes of chlamydospores, while colonies grown in the dark contained far fewer.

Advanced disease symptoms of Chalaropsis infection were characteristically ground-line lesions and areas of sloughed-off epidermal tissues. Chlamydospores were not found in these areas but rather on the internal walls of the stem pith chambers near the ground line. In culture, chlamydospores were found abundantly in Chalaropsis colonies grown in the dark but seldom in colonies grown in the light. These results confirmed that chlamydospore development in Chalaropsis is inhibited by the presence of light.

The results of isolation attempts proved that the development of these isolates of Chalaropsis thielavioides and Thielaviopsis basicola on poinsettias is restricted to nonchlorophyllous tissues. Both fungi were frequently isolated from the roots and ground-line stem tissues of diseased poinsettias but never from the upper stems, leaves, or flowers.

Both isolates of Thiclaviopsis grew best in culture on media with a $\mathrm{pH}$ range of $6.0-7.0$. The Chalaropsis isolate grew best on agar media with a $\mathrm{pH}$ range of 7.0-8.0. The greatest growth of Chalaropsis occurred at $30^{\circ} \mathrm{C}$. The optimum temperature for growth of both isolates of Thielaviopsis was $25^{\circ} \mathrm{C}$.

The results of the pathogenicity tests showed Chalaropsis thielavioides to be a weak pathogen. This fungus was probably not capable of producing its own infection site. It was capable of producing disease symptoms on poinsettias similar to the symptoms produced by Thielaviopsis after it had entered the host plant through wounds.

Thiclaviopsis was not restricted to wounds for entry. Pathogenicity tests showed that this fungus could produce appreciable amounts of disease on unwounded host plants, although wounding did increase disease incidence.

Similarities between Chalaropsis thielavioides and Thielaviopsis basicola were numerous. Morphology and colony characteristics indicated a possible relationship between these two genera. Growth factors, dimensions of comparable structures, similar vegetative and reproductive structures, and the production of similar disease symptoms on poinsettias were some of the characteristics that these two fungi had in common. Some specific factors such as the location of chlamydospore production and pathogenicity on poinsettias were points in which the two were different. $T$. basicola is important for its role as a component in the root rot complex of numerous plants, including poinsettias. C. thielavioides is not of major importance as a plant pathogen. The work presented here proves that Chalaropsis is a weak pathogen on poinsettias. 


\section{LITERATURE CITED}

Allisox, C. C. 1938. Physiologic specilization of Thielaviopsis basicola on tobacco. Phytopathology 28:1. (Abstract)

Baker, KenNeth F. 1953. Chalaropsis root rot of rose. Plant Disease Reporter 37:430 433.

and H. EArL Thomas. 1946. Failure of bud and graft unions of rose induced by Chalaropsis thielavioides. Phytopathology 36:281-291. , Lily H. Davis, and H. EarL Thomas. 1953. Grafting failure of ornamentals induced by Thiclaviopsis basicola. Plant Disease Reporter 37:526.

Batemian, D. F. 1960. The influence of $\mathrm{pH}$ on growth of Thielaviopsis basicola in culture and the development of Thielaviopsis root rots of poinsettia and bean in soil. Phytopathology 50:628. (Abstract)

1962. Relation of soil $\mathrm{pH}$ to development of poinsettia root rots. Phytopathology 52:559-566.

1963. Factorial analysis of environment and pathogens in relation to development of the poinsettia root rot complex. Phytopathology 53:509-516.

and A. W. Disiock. 1959. The influence of temperature on root rots of poinsettia caused by Thielaviopsis basicola, Rhizoctonia solani, and Pythium ultimum. Phytopathology 49:641-647.

Blank, L. M., P. J. Leyendecker, JR., and R. M. Nakayama. 1953. Observations on black root rot symptoms on cotton seedlings at different soil temperatures. Plant Discase Reporter 37:473-476.

Boerema, G. H. 1959. Chalaropsis thielavioides on carrots prepacked in perforated polyethylene bags (in Dutch, English summary). Verslagen von den Plantenziektenkundigen dienst te Wageningen 134:158161. (English abstract in Review of Applied Mycology 41:348.)

Christias, Christos, and Kenneth F. Baker. 1967. Chitinase as a factor in the germination of ehlamydospores of Thielaviopsis basicola. Phytopathology 57:1363-1367.

DE LA IsLA, M. DE L. 1962. The Agave atrovirens base rot. Agricultura Tecnica en Mexico 2:46-47. (Abstract in Biological Abstracts 46:6970.)

Dniock, A. W. 1951. Poinsettia trouble a result of root rot. New York State Flower Growers Bulletin 69:4-8.

Hamono, Joxce B. 1935. The morphology, physiology and mode of parasitism of a species of Chalaropsis infecting nursery walnut trees. Journal of Pomology and Horticultural Science 13:81-107.

Jounson, Jamies, and R. E. Hartman. 1919. Influence of soil environment on the root rot of tobacco. Journal of Agricultural Research 17:41-86.

Johnson, E. M., and W. D. VAlleau. 1935. Cultural variations of Thielaviopsis basicola. Phytopathology 25:1011-1018.

Keller, JohN R, 1954. Conditions influencing Thielaviopsis root rot of poinsettias. Phytopathology 44:389. (Abstract)

and Howard S. Potter. 1954. Thielaviopsis associated with root rot of some ornamental plants. Plant Disease Reporter 38:354-355.

_.., and James B. Shanks. 1955. Poinsettia root rot. Phytopathology 45:552558.

King, C. J., and J. T. Presley. 1942. A root rot of cotton caused by Thielaviopsis basicola. Phytopathology 32:752-761.

Klafman, W. L., and Jewveus Craig. 1960. Sterilization of agar media with propylene oxide. Phytopathology 50:868.

Lamb, Hownard, Ernest Wright, and Ross W. Davidson. 1935. A root rot of Chinese elns. Phytopathology 25:652-654.

Leyendecker, Philip J., JR. 1952. Root rot of cotton caused by Thielaviopsis basicola discovered in the upper Rio Grande valley of Texas. Plant Disease Reporter $36: 53$.

LroyD, A. B., and JohN L. Lockwood, 1961. Pathogenicity of Thielaviopsis basicola on peas. Plant Disease Reporter 45:422-424. and 1962. Precautions in isolating Thielaviopsis basicola with carrot discs. Phytopathology 52:1314-1315. and 1963. Effect of soil temperature, host variety, and fungus strain on Thielaviopsis root rot of peas. Phytopathology 53:329-331.

Longree, Karla. 1940. Chalaropsis thielavioides, cause of "black mold" of rose grafts. Phytopathology 30:793-807.

LuCAs, G. B. 1955. The cardinal temperatures and $\mathrm{pH}$ response of Thielaviopsis basicola. Mycologia 47:793-798.

Manning, W. J., F. J. Campbell, P. M. PAPIA, and P. A. Hughes. 1970. Effectiveness of benomyl soil drenches for control of Thielaviopsis root rot of poinsettia. Plant Disease Reporter 54:328-330.

Milbrath, J. A. 1946. Black mold disease of Manetti rootstock. American Nurseryman $83(1): 5-6$.

Miller, Patrick M. 1955. V-8 juice agar as a general-purpose medium for fungi and bacteria. Phytopathology 45:461-462.

Ostazeski, Stanley A. 1966. Thiclaviopsis basicola on greenhouse-grown birdsfoot trefoil (Lotus corniculatus). Plant Disease Reporter 50:825-827.

Papavizas, G. C., and P. B. Adams. 1969. 
Survival of root-infecting fungi in soil. XIL. Germination and survival of Thielaviopsis basicola in fallow soil and in soil adjacent to germinating bean seed. Phytopathology 59:371-378.

Perry, Robert Stephen. 1969. A comparative study of two components of the poinsettia root rot complex. M.S. Thesis. University of lllinois, Urbana, $71 \mathrm{p}$.

Peterson, J. L. 1967. Root and crown rot of perennial phlox caused by Thielaviopsis basicola. Plant Disease Reporter 51:436437.

Presley, John T. 1947. Thielaviopsis root rot of cotton in Mississippi. Plant Disease Reporter $31: 152$

RaAbe, R. D., and J. H. Hurlimann. 1970. Fungicide mixes for poinsettia root rot control. California Agriculture 24(1):910.

Rawlings, Ralph Edmund. 1940. Observations of the cultural and pathogenic habits of Thielaviopsis basicola (Berk. \& Br.) Ferraris. Missouri Botanical Garden Annals 27:561-598.

SHERBAKoFF, C. D. 1940. An occurrence on cotton of black root rot caused by Thiela- viopsis basicola. Phytopathology 30:707. (Abstract)

Staffeldt, E. E. 1959. Thielaviopsis basicola a part of the cotton (Gossypium hirsutum) seedling disease complex in New Mexico. Plant Disease Reporter 43:506-508.

Stover, R. H. 1950. The black rootrot disease of tobacco. I. Studies on the causative organism Thielaviopsis basicola. Canadian Journal of Research 28:445-470.

Tompkins, C. M., and J. T. MIDDLeton. 1950. Etiology and control of poinsettia root and stem rot caused by Pythium spp. and Rhizoctonia solani. Hilgardia 20(9):171182.

Tsao, Peter H., and S. D. Van Gundy. 1960. Effect of soil temperature on pathogenesis of Thielaviopsis basicola on sweet orange roots. Phytopathology 50:657. (Abstract) and 1962. Thielaviopsis basicola as a citrus root pathogen. Phytopathology 52:781-786.

Wright, ERnest. 1942. Chalaropsis root rot of Chinese elm. American Nurseryman $75(1): 7-9$.

YARwOOD, C. E. 1946. Isolation of Thielaviopsis basicola from soil by means of carrot disks. Mycologia 38:346-348. 


\section{B}

Black mold fungus, 422

Black root rot disease, 420

C

Carrots

isolation medium, 422,425

source of C. thiclatioides, 422,447

Chains

chlanydospores, 425-430, 449

conidia, 428,433

Chalaropsis root rot, 444

Chalaropsis thiclatioides

colony characteristics, 433,434

component of poinsettia root rot complex, 420,447

environmental factors, influence on growth, $420,422,435-442,446-449$

hosts, 421, 430, 446

isolates, $\mathbf{4 2 2}$

morphology, 422, 426, 429-431, 433, 446

on poinsettias, $420,430,434,435$, $442-444,446,447,449$

pathogenicity, 420, 421, 423,442, 446, 449

rate of growth, 433-435, 438, 439,446

surface contaninant on carrots, 422,447

Colonies

C. thiclavioides, $429,433-436$

T. hasicola, 425, 429, 430, 435-438, $440-442,447$

zonation, $429,430,434,438$

Comparisons of $T$. basicola and $C$. thiclavioides, $420,422,426,434,436,442,447,449$

\section{E}

Envirommental factor:

light, 426,446

$\mathrm{pH}, 421,426,446$

temperature, $421,422,426,446$

Euphortia pulcherrima Willd., 419

Fungal structures

chlamydospores, $421,426,428-430$, $433-442,445-447,449$

endoconidia, 423, 425-431, 433-436, $438-440,442,444-446$

endoconidiophores, $425-431,434,436-438$

mycclium (hypha), dark, 426, 428-430,

$434-436,438,440-442,446$

mycelium (hypha), hyaline, 425, 428-430, $4.33-436,438-440,442.446$

\section{G}

Germination of spores, 426, 429, 433, 446 Griuft failure, 422

$\mathrm{H}$

Host-pirasite contact, methods of initiating, $425,441,442$
Hosts

C. thiclacioides, 421

T. hasicola, 420,421

\section{1}

Incidence of disease, $421,441-447$

Intermal collar rot disease, 420

Light

effect on rate of growth

C. thiclatioides, $424,435,439-442$, $447-4.19$

T. basicola, 424, 430, 440-442, 447-449

influence on chlamydospore production, 430 , $435,439-442,449$

M

Measurcments of fungal structures

Chalaropsis, 430, 431, 433, 448

Thielatiopsis, 425, 426, 428, 448

Media

agars

acidic, $421,423,436,438$

basic, $421,423,436-438$

cabbage infusion, 422,435

carrot dextrose, 422,435

corn meal, 422,435

lima bean, 422,435

malt, 422,435

Noble, 422,435

poinsettil, $422,423,435,447$

potato dextrose, $422-424,429,435$

prune, 422,435

V-8 juice, $423-425,427,429,431$, $433-435,439-441,448$

broths

potato dextrose, $423,424,435,442$

$\mathrm{V}-8$ juicc dextrose, $423,424,435,442$

Methods

light studies, 424

microscopic examinations, 423

pathogenicity tests, 424,425

$\mathrm{pH}$ studies, 423,424

temperature studies, 424

Pathogenicity tests

results of, $442-446,449$

techniques used, 425

$\mathrm{pH}$

effect on rate of growth

C. thiclavioidles, 435-437, 446, 448, 449

T. basicola, 421, 435-438, 446, 448, 449

influence on

disease development, 419,421

growtl of fungi in culture, 421, 423, 424,

$435-438,446,449$

growth of fungi in soil, $419,421,446$ 


\section{Poinsettia}

agar component, 423

as host, $419,442,446,447$

maintenance, 424,446

symptoms produced on

C. thiclavioides, 442,446

T. basicola, 430, 443, 445

varieties, $423,424,447$

Poinsettia agitr, 422, 423, 435, 447

Propylene oxide, 425

Pythium root rot, 419

Pythium ultimum, 419, 420, 447

\section{R}

Results

light studies, 439-442, 447, 449

microscopic examinations, 425-435, 449

pathogenicity tests, $442-446,449$

pH studies, 436-438, 449

temperature studies, $\mathbf{4 3 8 , 4 3 9 , 4 4 9}$

Rhizoctonia root rot, 419

Rhizoctonia solani, 419, 420, 447

Root rot complex, $419,420,447$

\section{$\mathrm{S}$}

Signs of pathogens

C. thielavioides, 434, 435, 442, 445-447, 449

T. lrasicola, 430, 444-447, 449

Soil-drencl method results, 442,446

technique, 425

Soil pH, 419, 421

Soil-probe method results, 442, 414-446

technique, 425

Stem-incision method

results, 442,443 techniruc, 425

Sterilization

host tissue's, $\mathbf{4 2 5}$

isolation material, 425

Symptoms of disease

cutused by $C$. thiclavioides, 420,442 , $444-147,449$

cumsed by $P$. ultimum, 419

cuused by $R$. solani, 419

caused by $T$. basicola, 419, 420,430, $443-447,449$

used to evaluate pathogenicity, 425, 442

\section{T}

Temperature

effect on rate of growth

C. thiclatioides, 422, 438, 439, 446, 448,449

T. busicola, 421, 438, 439, 446, 448, 449 influence on

direase development, $419,421,446,447$

growtl of fungi in culture, $421,422,424$,

$436,438,439,446,448,449$

growth of fungi in soil, 419, 421, 424, 446

Thichaviopsis basicola

colony characteristie's, 421, 429, 440,441

component of poinsettia root rot complex.

$419,420,447$

environmental factors, influence on growth, $420,421,436-442,446-149$

hosts, $419-422,426,446$

isolates, $422,436-438,440-143,446$

morpliology, $125-430,446$

on poinsettias, $419,420,430,443-447,449$

pathogenicity, $423,446,449$

rate of growth, $429,435,436,438,440$, 442,446

Thiclaviopsis root rot, $419,421,443,445$ 




\section{BULLETIN}

Volume 29, Article 4.-The Thrips, or Thysanoptera, of Illinois. By Lewis J. Stannard. May, 1968. 338 p., frontis., 310 fig., bibliogr., index.

Volume 30, Article 1.-Largemouth Bass and Other Fishes in Ridge Lake, Illinois, 19411963. By George IV. Bennett, H. Wickliffe Adkins, and William F. Childers. September, 1969. 67 p., 10 fig., bibliogr., index.

Volume 30, Article 2.-Dynamics of OneSpecies Populations of Fishes in Ponds Subjected to Cropping and Additional Stocking. By D. Homer Buck and Charles F. Thoits II1. March, 1970. 97 p., 10 fig., bibliogr., index.

Volume 30, Article 3.-Migrational Behavior of Mallards and Black Ducks as Determined from Banding. By Frank C. Bellrose and Robert D. Crompton. September, 1970. 68 p., frontis., 25 fig., bibliogr., index.

Volume 30, Article 4.-Fertilization of Established Trees: A Report of Field Studies, By Dan Neely, E. B. Himelick, and Webster R. Crowley, Jr. September, 1970. 32 p., frontis., 8 fig., bibliogr., index.

Volume 30, Article 5.-A Survey of the Mussels (Unionacea) of the lllinois River: a Polluted Stream, By William C. Starrett. February, 1971. 137 p., 17 fig., bibliogr., index.

Volume 30, Article 6.-Comparative Uptake and Biodegradability of DDT and Methoxychlor by Aquatic Organisms. By Keturah A. Reinbold, Inder P. Kapoor, William F. Childers, IVillis N. Bruce, and Robert L. Metcalf. June, 1971. 12 p., frontis., 5 fig., bibliogr., index.

\section{BIOLOGICAL NOTES}

64.-The Value of In Vitro Fungicide Tests. By Dan Neely. January, 1969. 8 p., bibliogr. 65.-Trends in Pheasant Abundance in Illinois: 1958 to 1968. By Ronald F. Labisky. May, 1969. 8 p., 4 fig., bibliogr.

66.-Tree and Shrub Hosts of Verticillium albo-atrum. By E. B. Himelick. July, 1969. 8 p., bibliogr.
67.-Concentrations of Chemical Elements in Pheasant Tissues. By William L. Anderson and Peggy L. Stewart. April, 1970. 15 p., bibliogr.

68.-Illinois Birds: Mimidae. By Richard $R$. Graber, Jean W. Graber, and Ethelyn L. Kirk. September, 1970. 38 p., 32 fig., bibliogr.

69.-The Life History of the Dusky Darter, Percina sciera, in the Embarras River, Illinois. By Lawrence M. Page and Philip W. Snith. September, 1970. 15 p., II fig., bibliogr.

70.-An Ecological Study of Four Darters of the Genus Percina (Percidae) in the Kaskaskia River, Illinois. By David L. Thomas. December, 1970. 18 p., II fig., bibliogr.

71.-A Synopsis of Common and Economic Illinois Ants, with Keys to the Genera (Hymenoptera, Formicidae). By Herbert H. Ross, George L. Rotramel, and Wallace E. LaBerge. January, 1971. 22 p., 27 fig., bibliogr.

72.-The Use of Factor Analysis in Modeling Natural Communities of Plants and Animals. By Robert IV. Poole. February, 1971. 14 p., 14 fig., bibliogr.

73.-A Distributional Atlas of Upper Mississippi River Fishes. By Philip W. Smith, Alvin C. Lopinot, and William L. Pflieger. May, 1971. 20 p., 2 fig., 107 maps, bibliogr.

74.-The Life History of the Slenderhead Darter, Percina phoxocephala, in the Embarras River, Illinois. By Lawrence M. Page and Philip W. Smith. July, 1971. 14 p., 10 fig., bibliogr.

\section{CIRCULAR}

46.-Illinois Trees: Their Diseases. By J. Cedric Carter. June, 1964. (Third printing, with alterations.) 96 p., frontis., 89 fig.

49.-The Dunesland Heritage of Illinois. By Herbert H. Ross (in cooperation with Illinois Department of Conservation). August, 1963. 28 p., frontis., 16 fig., bibliogr.

51.-1llinois Trees: Selection, Planting, and Care. By J. Cedric Carter. August, 1966. 123 p., frontis., 108 fig.

52,-Fertilizing and Watering Trees. By Dan Neely and E. B. Himelick. December, 1968. (Second printing.) 20 p., 9 fig., bibliogr.

53.-Dutch Elm Disease in Illinois. By J. Cedric Carter. October, 1967. 19 p., frontis., 17 fig.

\section{List of available publications mailed on request}

No charge is made for publications of the Illinois Natural History Surver. A single copy of most publications will be sent free to anyone requesting it until the supply becomes low. Costly publications, more than one copy of a publication, and publications in short supply are subjects for special correspondence. Such correspondence should identify the writer and explain the use to be made of the publication or publications. 